\title{
Procesos ejecutivos en la España castellana durante la Edad Moderna
}

\section{Executive processes in the Castilian Spain during the Modern Age}

\author{
Pedro Andrés PORRAS ARBOLEDAS \\ Catedrático acreditado de Historia del Derecho \\ Departamento de Historia del Derecho \\ Instituto de Metodología e Historia de la Ciencia Jurídica \\ Facultad de Derecho. Universidad Complutense de Madrid \\ pporras@der.ucm.es
}

El trabajo de los autores es increible, y su cuidado, extraordinario; y han de ganar mucho para que al cabo del año no salgan tan empeñados que les sea forzoso hacer pleito de acreedores. ${ }^{1}$

Recibido: 17 de diciembre de 2012

Aceptado: 21 de enero de 2013

\section{RESUMEN}

La inmersión de los Reinos de Castilla en una economía monetaria durante los siglos modernos dará lugar a la improvisación de diversos expedientes para hacer frente a los casos de insolvencia; para ello durante el siglo XVI se ensayaron varios procedimientos, que acabarán cristalizando en el concurso de acreedores paradigmático, que se mantendrá incólume para procesos civiles y mercantiles hasta las Ordenanzas del Consulado de Bilbao (1737), que introducen el proceso de quiebra, nuevo paradigma de larga duración. Por el contrario, las ejecuciones singulares mantuvieron una gran estabilidad durante el período moderno.

PALABRAS CLAVE: Insolvencia, concurso de acreedores, quiebras, economía monetaria.

\begin{abstract}
The immersion of the Castilian Kingdoms in a monetary economy through the modern centuries will lead to the improvisation of various protocols to deal with insolvency cases. To serve this goal, several procedures were implemented during the sixteenth century, that eventually crystallized in the paradigmatic arrangement of creditors that will remain intact for civil and commercial proceedings until the Consulate of Bilbao Ordinances (1737), where bankruptcy proceedings were introduced: a new long lasting paradigm. On the other hand, the unique performances remained very stable during the modern period.
\end{abstract}

KEYWORDS: Insolvency, arrangement of creditors, bankruptcies, monetary economics.

\footnotetext{
${ }^{1}$ Miguel de Cervantes, «El Licenciado Vidriera», Novelas Ejemplares 1, Madrid, 1995, p. 352. «Autores» debe entenderse en el sentido de empresarios teatrales y/o directores de compañía.
} 


\section{RÉSUMÉ}

Pendant la modernité, l'immersion des royaumes de Castille dans une économie monétaire conduira à improviser différents protocols pour faire face à l'insolvabilité. Des différentes procédures seront ainsi instituées au cours du XVI $\mathrm{XI}^{\mathrm{e}}$ siècle, qui vont finalement cristalliser dans le paradigme du concours de créanciers, qui restera intact pour les procédures civiles et commerciales jusqu'à ce que les ordonnances du Consulat de Bilbao (1737), qui ont amorcé une procédure de faillite, donnerent ainsi lieu à un nouveau paradigme qui s'avérera de longue durée. Au contraire, les éxecutions singulières resteront très stables pendant toute la période moderne.

MOTS CLÉ : Insolvabilité, faillite, concours de créanciers, économie monétaire.

\section{ZUSAMMENFASSUNG}

Der Schritt der Könige von Kastilien hin zur Geldwirtschaft in der frühen Neuzeit führte zu improvisierten Reaktionen von verschiedenen Unternehmen, um der Insolvenz zu entgehen; durch diese Reaktionen wurden im Verlauf des 16. Jahrhunderts verschiedene Prozedere eingeführt, die letztendlich im Konkurs die typisierten Gläubiger herauskristallisierten, die sich unversehrt durch Zivil- und Wirtschafts-/Handelsprozesse hielten bis zu den "Ordenanzas del Consulado de Bilbao" (1737), welche den Konkursprozess und damit ein neues Paradigma von langer Dauer einführten. Ganz im Gegensatz hierzu führte die Einzelvollstreckung zu einer großen Stabilität in der Frühen Neuzeit.

SCHLÜSSELWÖRTER: Insolvenz, Konkurs der Gläubiger, Konkurs, Geldwirtschaft.

SUMARIO: 1. Justificación de la investigación. 2. Posibilidades de investigación en archivos. 3. Antecedentes históricos. 4. Procesos ejecutivos en la época moderna. 4.1. La ejecución singular. 4.2. Proceso de cesión de bienes, según disposición de Cortes de 1458. 4.3. El proceso de aceptación de bienes en pago a tasación. 4.4. La espera: acuerdos privados, expedientes y procesos. 4.5. El concurso de acreedores. 4.5.1. Concursos especiales: nobleza y concejos. 4.5.2. Pleitos de tercería. 4.6. Procesos y expedientes especiales: allanamiento, cesión de parte de pensión y consignación eclesiástica. 4.7. Las quiebras anteriores a 1737: tipos de procesos. 4.8. La quiebra en el Consulado de Bilbao a partir de 1737. 5. Conclusiones.

\section{Justificación de la investigación}

Allá por el año 1998 me planteé la posibilidad de realizar una amplia investigación que diera lugar a la presentación de una tesis doctoral en Derecho, que redondeara mi preparación como historiador del Derecho, una vez que en 1981 ya había leído mi tesis de Historia. Para ello me decanté por introducirme en el ámbito del Derecho concursal, tanto en lo relativo a los antecedentes del concurso de acreedores como a los de la quiebra, sin preocuparme de su carácter civil o mercantil, habida cuenta de que los hombres modernos no se plantearon esa cuestión, salvo en los contados casos de los lugares donde existía un Consulado.

Sin embargo, la elección del tema no fue un acto derivado de una inclinación específica por el mundo de la insolvencia, sino que vino dada por el hallazgo de unos procesos en archivo, que rápidamente llamaron mi atención, entre muchos otros. En años anteriores al 1998 había estado inventariando los fondos de archivo del Conde de Bornos —entonces en la sección Diversos, Títulos y Familias, del Archivo Histó- 
rico de Madrid; hoy en la Sección Nobleza, del mismo Archivo, en Toledo²—, buscando entre sus casi 900 legajos los papeles relativos al fundador de la Casa, el artillero Francisco Ramírez de Madrid. ${ }^{3}$

Entre los papeles de la Casa de Bornos se hallaban, por un lado, el concurso de Sebastián de Larrauri, regidor y depositario general de la ciudad de Burgos, que se extendió entre 1602 y 1607, y, por otro, la quiebra del banco de Jácome Mortedo y compañía (1602-1603); ${ }^{4}$ a partir de ahí, en mis visitas a otros archivos me fui dando cuenta progresivamente de las posibilidades del tema, merced a la gran cantidad de procesos y expedientes que estaban siendo descritos tanto en archivos provinciales como en nacionales.

Naturalmente, un breve examen de la bibliografía existente, sin duda de valor, me hizo darme cuenta de que el tema podía ser explotado con bastante más cantidad de documentación inédita de lo hecho hasta el momento. ${ }^{5}$ Para mí, el trabajo a realizar tenía el aliciente de permitirme manejar un volumen amplísimo de información casi totalmente desconocida, con un elenco reducido de obras de literatura jurídica ${ }^{6} \mathrm{y}$ de bibliografía moderna. ${ }^{7}$

\footnotetext{
2 Pedro A. Porras Arboledas, «Inventario del archivo del conde de Bornos», Espacio, Tiempo y Forma, Serie III, Historia Medieval, VIII, 1995, pp. 183-289.

${ }^{3}$ Pedro A. Porras Arboledas, Francisco Ramírez de Madrid (144?-1501). Primer madrileño al servicio de los Reyes Católicos, Madrid, 1996.

${ }^{4}$ Cuando este archivo estaba en Madrid estos dos procesos se hallaban, respectivamente, en los legajos 900 y 1.502; al inventariarse de nuevo en Toledo, cambiaron las signaturas (en la actualidad tienen las siguientes, 831/1 y 362/1). El de Mortedo es un cuadernillo en pergamino, incompleto, de 12 folios; el expediente de Larrauri alcanza los 132 folios. El hecho de que consten estos documentos en un archivo señorial se debe a que alguno de sus mayorazgos debió de adquirir, mediante venta judicial, algunos bienes concursados.
}

${ }^{5}$ Me refiero tanto a la tesis doctoral del profesor Alejandre García (La quiebra en el Derecho Histórico Español anterior a la Codificación, Sevilla, 1970), como a los posteriores de Patricia Zambrana Moral (Derecho concursal histórico I. Trabajos de investigación, Barcelona, 2001, e Iniciación histórica al Derecho concursal. Planteamientos institucionales, Málaga, 2001).

${ }^{6}$ En especial, las obras de Amador Rodríguez (Tractatus de concursu et privilegiis in bonis debitoris et de praelationibus eorum..., Madrid, 1616) y Francisco Salgado de Somoza (Labyrinthus creditorum concurrentium ad litem per debitorem communem inter illos causatam, Venecia, 1653), ambas obras con ediciones posteriores. El resto de la literatura jurídica utilizable, recogida en la Iniciación histórica de Patricia Zambrana, p. 9.

${ }^{7}$ Sin ánimo de construir una nota bibliográfica exhaustiva, es preciso al menos exponer una relación de las obras de mayor interés para nuestro intento. En el ámbito del derecho romano deben citarse las obras de Siro Solazzi (Il concorso dei creditori nel diritto romano, Napoli, 1935-1940, 4 volúmenes) y Vincenzo Giuffrè («La C.D. "Lex Julia” de bonis cedendis», Labeo. Rassegna di Diritto Romano, XVIII, 1972, pp. 173-191; contestó a algunas objeciones realizadas sobre la crononolgía de esa ley en la misma revista, en el número de 1984, pp. 90-93). Más recientemente, en nuestro país, deben mencionarse los trabajos de Ottorino Clerici (Sul beneficium competentiae in diritto romano, Napoli, 1982), Rosalía Rodríguez López ( «In solutum cessionis venditionisque documentum (Consideraciones sobre el papiro 34 de Ravenna)», Revue Internationale des Droits de l'Antiquité, XLV, 1998, pp. 537-561) y, sobre todo, el de María Pilar Pérez Álvarez (La bonorum venditio. Estudio sobre el concurso de acreedores en el 
Para ello decidí enviar una circular a todos aquellos archivos donde previsiblemente pudiera hallarse documentación relativa a estos temas, más allá de los que es-

derecho romano clásico, Madrid, 2000). Menor interés reviste el trabajo de Pietro Cerami y Aldo Petrucci (Diritto commerciale romano. Profilo storico, Torino, 2010 ( $3^{\mathrm{a}} \mathrm{ed}$.); tan sólo se ocupa de la quiebra bancaria someramente).

La historia de la insolvencia, en general, ha sido trabajada en Italia por Alfredo Rocco (Il fallimento. Teoria generale e origine storica, Milano, 1962; donde defiende la importancia del derecho concursal estatutario y niega virulentamente, frente a J. Kohler, la influencia de la doctrina española, extendida por Salgado de Somoza) y por Umberto Santarelli (Per la Storia del fallimento nelle legislazioni italiane dell'Età Intermedia, Padova, 1964; centrado en la legislación italiana de los siglos XIII a XVIII. También, Mercanti e società tra mercanti, Torino, 1998 ( $3^{\mathrm{a}}$ edición); interesa especialmente el capítulo $4^{\mathrm{o}}$ : «Un "rischio del mestiere": il fallimento»).

En Francia, Claude Dupouy (Le droit des faillites en France avant le Code de commerce, Paris, 1960; trabajo de carácter dogmático, sin considerar la influencia italiana); también son de utilidad las páginas de los manuales al uso, como el de Jean Hilaire (Introduction historique au Droit commercial, Paris, 1986; dedica el capítulo $4^{\circ}$ de la segunda parte a «la faillite», además de dar valiosas indicaciones bibliográficas en pp. 339-341) o el de Romuald Szramkiewicz (Histoire du droit des affaires, Paris, 1989; trata brevemente la insolvencia en los tres período cronológicos en que divide su obra). También Patricia Zambrana («Algunas soluciones para la insolvencia del deudor en el derecho medieval francés», Anuario de Estudios Medievales, XXIX, 1999, pp. 1.185-1.200; hace un recorrido por la cesión de bienes a partir de la legislación local).

Para Alemania, Lothar von Seuffert, Zur Geschichte und Dogmatik des Deutschen Konkursprozess, Nördlingen, 1888. Sobre la influencia de Salgado de Somoza en Alemania, Niceto Alcalá-Zamora y Castillo, Un español mal comprendido: Salgado de Somoza en la literatura alemana sobre concurso de acreedores, Madrid, 1932.

Por lo que se refiere a España, además de los trabajos ya citados, es de interés el manual de Fernando Cerdá Albero e Ignacio Sancho Gargallo (Curso de Derecho Concursal, Madrid, 2000; con una interesante introducción histórica), de Juana Pulgar Ezquerra (El presupuesto objetivo de la quiebra en derecho español, Almería, 2000; realiza un excursus histórico, decantándose por la tesis de Juan Antonio Alejandre de que el derecho estatutario italiano no influye en el derecho concursal castellano, sino que éste nace de la extensión de la cesión de bienes ya desde las Partidas); de Santos M. Coronas (Derecho Mercantil castellano, León, 1979; interesa el primero de los dos trabajos incluidos, «La jurisdicción mercantil castellana en el siglo XVI»); de Laura López de la Cruz (La cesión de bienes a los acreedores, Valencia, 2003; dedicado a la cesión extrajudicial, por vía contractual, que entiende debe distinguirse de la dación en pago o la adjudicación en pago por deudas); de Francisco Muñoz Conde (El delito de alzamiento de bienes, Barcelona, 1995; incluye una pequeña referencia histórica, de la que interesa la ley 89 de las Cortes de 1480, contra los banqueros y mercaderes que se alzaban con bienes ajenos) y de Natividad Rapún Gimeno (La insolvencia en el derecho histórico aragonés. La quiebra. Siglos XVI-XVIII, Pamplona, 2011).

En el ámbito del Consulado de Burgos, disponemos del estudio de Manuel Basas Fernández (El Consulado de Burgos en el siglo XVI, Burgos, 1963), así como el análisis de una quiebra bancaria («La quiebra del banco Aragón-Aguilar, de Burgos, en 1557», Revista de Derecho Mercantil, XXXII, 1961, pp. 349-379); sobre el Consulado de Bilbao, la clásica obra de Teófilo Guiard Larrauri (Historia del Consulado y Casa de Contratación de Bilbao y del comercio de la villa, Bilbao, 1914); en cuanto al Consulado limeño contamos con el trabajo de $\mathrm{M}^{\mathrm{a}}$ Encarnación Rodríguez Vicente (El Tribunal del Consulado de Lima en la primera mitad del siglo XVII, Madrid, 1960) y el trabajo inédito de Manuel Enrique Valverde González (Una visión parcial del concurso de acreedores a través de la casuística dieciochesca. Real Audiencia de Lima - Real Tribunal del Consulado (1735-1780), Lima, 1998; tesis para 
taba acostumbrado a visitar. La respuesta fue masiva y, en la mayoría de los casos, positiva, por lo que durante un año me dediqué a viajar de archivo en archivo recolectando información — todo ello sin ningún tipo de ayuda, a mis propias expensas- Al final me encontré con tal cúmulo de procesos concursales que, he de reconocerlo, me superó, de modo que lo ingente de la labor, así como otras circunstancias personales, que aquí no vienen al caso, me hicieron que no pudiera coronarla entonces, como había sido mi deseo. De hecho, acabaría concibiendo otro tema de tesis - el juicio de residencia-, que aún tengo en el tintero; lástima que las ansias recaudatorias de derechos de esta universidad hayan frustrado mis deseos de presentar esta segunda investigación como trabajo de doctorado. A estas alturas confieso que ya me la trae al fresco ese reconocimiento administrativo. Como diría Gabriel Celaya, «Cuando ya nada se espera /... / estamos tocando el fondo».

En cualquier caso, cuando en 2005 se celebró, a escasos metros de mi despacho, un concurso de habilitación para cátedras de Historia del Derecho me pareció que no podía dejar de presentarme a dichas pruebas, por no incurrir en cobardía académica. De la actuación en aquella ocasión de la mayoría tanto del tribunal como de mis compañeros de departamento - teóricamente situados a una distancia similar a la mía en cuanto al lugar de autos - prefiero (como Cervantes respecto del pueblo de don Quijote) no acordarme; al menos conocí a un grupo de coopositores o cohabilitandos que merecían la pena, ninguno de los cuales, por cierto, obtuvo ninguna de las dos plazas en juego. La verdad es que para aquella ocasión preparé como lección magistral el borrador del trabajo que ahora presento en este artículo, cuya dedicatoria es obvia. Confío en que, una vez roto el fuego con estas líneas, en años sucesivos vaya sacando trabajos sectoriales, para dar salida al ingente material recolectado. De hecho, si no he publicado antes este estudio ha sido porque esperaba que, habiendo sido acreditado para catedrático (en enero de 2010), la oposición correspondiente no tardaría en producirse, pues pensaba usar este mismo discurso; una vez más incurrí en grave error,

obtener el título de abogado en la Universidad Nacional Mayor de San Marcos, que el autor tuvo la gentileza de remitirme). Así mismo, es de interés el estudio de María Encarnación Rodríguez Vicente («Una quiebra bancaria en el Perú del siglo XVII», Anuario de Historia del Derecho Español, XXVI, 1956, pp. 707-739).

Junto a la tesis del profesor Alejandre, probablemente la obra que más influencia ha tenido en España sobre estos temas ha sido la de Francisco Tomás y Valiente («La prisión por deudas en los derechos castellano y aragonés», Anuario de Historia del Derecho Español, XXX, 1960, pp. 249-489). Recientemente ha vuelto sobre ese tema Álvaro Pérez-Ragone («La progresiva humanización de los procesos de insolvencia de personas naturales: desde la servidumbre e infamia hasta los procesos concursales de consumidores», Revista de Derecho de la PUC de Valparaíso, XLI, 2013, pp. 641-678).

Sobre las quiebras sevillanas en el comercio con las Indias, los trabajos de Antonio-Miguel Bernal y Antonio García-Baquero (Tres siglos del comercio sevillano (1598-1868), Sevilla, 1976), y del primero de ellos, con la colaboración de Isabel Martínez Ruiz (La financiación de la Carrera de Indias (14921824): dinero y crédito en el comercio colonial español, Sevilla, 1992).

Finalmente, sobre la vía ejecutiva, David Peláez Portales («Un juicio ejecutivo en la Granada del siglo XVII», Derecho y opinión, VIII, 2000, pp. 459-481). 
dado que las autoridades de esta universidad han demostrado tener muchas otras prioridades antes de dar curso a la justa promoción de su profesorado.

\section{Posibilidades de investigación en archivos}

Como decía, en torno a 1999, tras realizar una serie de catas exitosas en archivos madrileños, cántabros, gienenses y granadinos, decidí remitir una circular a centros documentales nacionales, provinciales, de Diputaciones, municipales y eclesiásticos de la España castellana, preguntando por la existencia de fondos sobre procesos concursales; la respuesta fue impresionante, de hecho, salvo en Galicia, ${ }^{8}$ Asturias, Extremadura ${ }^{9}$ y Canarias, en todas partes respondieron positivamente. Debe tenerse en cuenta que la meritoria labor realizada por los archiveros de estos centros en los últimos 30 años, describiendo fondos desconocidos antes, permite acometer estudios con amplio respaldo documental, algo que en los años en que el profesor Alejandre realizó su tesis no era posible.

He de decir que, independientemente de otras consideraciones, lo más enriquecedor de mi deambular por todo este cúmulo de archivos fue el conocer y tratar a archiveros y archiveras de una extraordinaria calidad humana y profesional, en su inmensa mayoría, lo que hace más lamentable la desaparición posterior de alguno de ellos, en plena juventud.

Por lo que se refiere a Cantabria, en su archivo provincial se localizan alrededor de 200 concursos de acreedores, inventariados, centrados en los siglos XVII y XVIII; los fondos pertenecen sólo a algunos valles, no a su totalidad. ${ }^{10}$ Sólo en el archivo municipal de Santillana del Mar se conservan 56 concursos, datados entre 1623 y $1818 .{ }^{11}$

Las tres provincias vascongadas cuentan con una riqueza envidiable en este campo: por lo que se refiere a Vizcaya, cuenta con fondos el archivo provincial - los relativos al área de las Encartaciones-y, sobre todo, el de la Diputación Foral, que reúne la documentación tanto de los corregimientos de Bilbao y Busturia como del Consulado

\footnotetext{
${ }^{8}$ Finalmente, a través de mi compañero el profesor Pedro Ortego conseguí alguna referencia procedente el Archivo de ese Reino (ARGalicia, Sección Vecinos, 10.584/91).

${ }^{9}$ Sí que debe de haber información en los fondos de la Audiencia de Extremadura, pero del siglo XVIII, época en que la documentación ya es muy abundante en todas partes, por ello en su momento no me desplacé allá.

${ }^{10}$ Pedro Andrés Porras Arboledas, «Concursos de acreedores en el Archivo Histórico Provincial de Cantabria (siglos XVI-XIX)», Altamira. Revista del Centro de Estudios Montañeses, LIII, 1998, pp. 229262. Estos mismos fondos, junto con otros del mismo archivo, han sido estudiados exhaustivamente por Tomás A. Mantecón, desde un punto de vista sociológico (Conflictividad y disciplinamiento social en la Cantabria rural del Antiguo Régimen, Santander, 1997).

${ }^{11}$ Fuentes documentales para la Historia de Santillana: Archivo Municipal de Santillana del Mar, Santillana del Mar, 1983 (introducción histórica de Rogelio Pérez-Bustamante, inventario y registro de Javier Ortiz Real y prólogo de Enrique Lafuente Ferrari).
} 
bilbaíno, a partir de 1590. Guipúzcoa también cuenta con una gran cantidad de documentación desde esa misma época en su archivo provincial o general (AGG), situado en Tolosa. Álava, por su parte, cuenta con fondos en distintos archivos municipales, en especial, el de Salvatierra, los cuales están perfectamente inventariados e informatizados desde antiguo por la Diputación Foral, ${ }^{12}$ en tanto que el archivo provincial atesora interesante documentación concursal desde el siglo XVII.

Por lo que se refiere a La Rioja, contienen fondos de los dos últimos siglos modernos el archivo provincial, el municipal de Logroño y el diocesano de Calahorra.

De los archivos castellano-leoneses cabe decir algo parecido a lo avanzado sobre los centros documentales vascos: por lo que se refiere a Burgos, he localizado concursos tanto en el archivo municipal como en el provincial, donde se documenta en especial la crisis de $1680,{ }^{13}$ si bien es lamentable la desaparición de los papeles de su Consulado. Algo similar hay que decir de los archivos segovianos, siendo excepcionales los fondos del provincial para el siglo XVI. En la misma provincia cabe citar el archivo del Marqués de Lozoya, así como el del duque de Alburquerque (en Cuéllar), con fondos de la casa de Alcañices, protagonista de un largo proceso concursal, así como la principal de Alburquerque. Igualmente son de interés los materiales conservados en el archivo provincial de Soria, con documentación de varios corregimientos. En el archivo provincial de Ávila interesa especialmente la sección facticia A, con abundante información judicial. En Palencia y en las tres provincias leonesas o apenas tenían documentación de interés o no se molestaron en contestar a mi circular. Es, sin embargo, en Valladolid donde se concentra el mayor cúmulo de documentación de esa comunidad autónoma, particularmente en el archivo de la Chancillería y en el General de Simancas; también resultó relevante la relación de concursos conservados en el archivo provincial, si bien el archivo de Simón Ruiz, allí guardado, apenas arrojó documentación de interés. ${ }^{14}$

En la capital de España se han conservado procesos concursales y documentación colateral en todos sus archivos: en el regional de la Comunidad de Madrid, entre los fondos de la Diputación (en especial, ventas judiciales) y en los archivos municipales allí depositados; en el archivo General de Palacio se localizaron concursos de criados de la Casa Real; en la Biblioteca de la Real Academia de la Historia, buen número de porcones sobre temas concursales; en el archivo de la Villa algunos flecos de procesos y, sobre todo, en el Histórico Nacional, entre los papeles de los Consulados de Cádiz, Canarias, México o Lima, además de consultas diversas.

\footnotetext{
${ }^{12}$ De hecho, cuando hice la mencionada consulta me contestaron, prácticamente, a vuelta de correo, con el envío de detalladas descripciones del centenar y medio de concursos conservados en los archivos municipales de la provincia.

${ }^{13}$ Pedro Andrés Porras Arboledas, «Concursos de acreedores en el Archivo Histórico Provincial de Burgos (siglos XVI-XIX)«, Cuadernos de Historia del Derecho, XII, 2005, pp. 355-372.

${ }^{14}$ Salvo la quiebra y pleito de acreedores de Cosme Ruiz (1526-1630), no conservado completo (Archivo Histórico Provincial de Valladolid, Archivo Simón Ruiz, 232) o algunos autos de la quiebra del banco de Cristóbal Rodríguez Muñoz, en 1601 (Idem, 244).
} 
En el área castellano-manchega sólo conservan documentación de interés las provincias de Toledo, Guadalajara y Cuenca. En la capital toledana hay información en el archivo provincial, en el municipal y en el de la Diputación, además de en el mencionado archivo del Conde de Bornos, sito hoy día en el AHN, sección Nobleza. Dentro de su provincia se han localizado algunos procesos en los municipales de Talavera de la Reina, La Iglesuela y Castillo de Bayuela. En Guadalajara se consultaron el archivo provincial y el de la Diputación. En Cuenca tienen documentación valiosa en el archivo diocesano, en el municipal y, muy especialmente, en el provincial, por lo que se refiere a su esplendoroso siglo XVI. ${ }^{15}$

En Murcia se visitaron tanto el archivo municipal como el provincial, con escasos resultados.

Finalmente, por lo que se refiere a Andalucía, nada se localizó en las provincias de Huelva, Córdoba, Málaga y Almería. En la provincia de Jaén aportaron información los archivos de la Diputación y el provincial, con escasos pero muy interesantes procesos de comienzos del siglo XVI, y, particularmente, el municipal de Úbeda, que guarda un tesoro de concursos de los siglos modernos, procedentes de su antiguo corregimiento. En Granada se ha localizado documentación relevante tanto en el archivo de la Diputación, como, sobre todo, en el de la Chancillería. En Sevilla se manejaron, con distintos resultados, los fondos del archivo diocesano, del archivo y biblioteca Colombina, del municipal y del provincial, pero el más relevante, obviamente, es el archivo de Indias. Por lo que se refiere a Cádiz, lo parco de la información que se me comunicó no justificó un desplazamiento allá.

\section{Antecedentes históricos}

La normativa romana primigenia relativa a la tutela del crédito preveía un procedimiento ejecutivo personal (per manus iniectio), de carácter privatista, que imponía la prisión por deudas a fin de constreñir al deudor al pago: una vez sentenciado a hacer el pago y sin que éste se produjera (plazo de 30 días), el deudor era manifestado por el acreedor ante el magistrado, llevándolo asido de la mano; el deudor debía presentar un defensor, que entablase la acción en su nombre; si no lo nombraba, debía permanecer encadenado en casa del acreedor durante 60 días. Era un tiempo para buscar una composición, pregonándose por los mercados su situación a fin de que terceros se hicieran cargo del pago. De no llegarse a un acuerdo, el acreedor podía mantenerlo en esclavitud, venderlo trans Tiberim o darle muerte. ${ }^{16}$

La Lex Poetelia Papiria (de alrededor del 326 a.C.) dio paso a la ejecución patrimonial (missio in bona). Según dicha ley, el pretor debería ser instado por los acree-

\footnotetext{
${ }^{15}$ Pedro Andrés Porras Arboledas, «La crisis económica en Cuenca bajo los Austrias. La crisis como hecho histórico y como problema jurídico», La economía conquense en perspectiva histórica, Cuenca, 2000, pp. 177-195.

${ }^{16}$ Los datos de este epígrafe están extractados de la citada obra del profesor Alejandre.
} 
dores, nombrándose un defensor de los bienes (curator bonorum), cuya función era tener bajo su protección dichos efectos en tanto los acreedores designaban un síndico o magister. El magister debía proceder a la venta en bloque de todo el patrimonio del fallido (bonorum venditio). El comprador (emptor bonorum) se subrogaba en la posición del deudor, siendo responsable hasta el límite del precio de adquisición del patrimonio. El deudor, entre tanto, no quedaba liberado, sino que caía en infamia y seguía siendo responsable por lo no pagado con cargo a sus bienes futuros. Se introducía una excepción para los senadores, locos, pródigos o impúberes, consistente en la venta al detall de los bienes (distractio bonorum), procedimiento que luego se generalizaría bajo Trajano.

El siguiente jalón del proceso vino representado por la Lex Iulia (de alrededor de 17 a.C.), en la que para evitar la consabida nota de infamia, se introdujo la cesión de bienes (cessio bonorum), constituyendo, pues, un beneficio tanto judicial como extrajudicial para el deudor; de este modo, éste eludía la infamia y la ejecución de su persona, si bien seguía respondiendo con cargo a sus bienes futuros a las cantidades que sus bienes no alcanzasen a satisfacer durante la cesión. Así mismo, se le concedía al deudor la retención de parte de sus bienes en concepto de alimentos (beneficium competentiae).

En opinión de Schultz, ${ }^{17}$ la cesión de bienes fue un privilegio excepcional; con la concesión por parte de Justiniano al heredero de la aceptación de la herencia con beneficio de inventario, se abrirá paso a la generalización de la cessio bonorum, quedando así postergada la ejecución personal.

Sea como fuere, lo cierto es que en la creación de un nuevo paradigma en Castilla en torno a la solución de los cada vez más numerosos casos de insolvencia, desde los inicios del siglo XVI, jugaron un papel destacado distintas instituciones tomadas por separado del universo jurídico romano: en primer lugar, la cessio bonorum con su correlato, el beneficium inventarii, así como la dación en pago (datio in solutum); el beneficium competentiae, en virtud del cual el juez, a requerimiento del concursado, retenía una cantidad determinada de sus bienes para atender sus necesidades más perentorias (alimentos). Además, jugó un papel fundamental la actio de dote, como garantía privilegiada para la mujer por sus bienes dotales; el principio prior tempore, potior iure, para la fijación del orden de pago de las hipotecas, salvo en el caso de las privilegiadas; la condemnatio in id quod debitor facere potest, como límite a la ejecución patrimonial, y el estilo non secundum ius dictat (solidum per libram), que permitía minorar los créditos de cada cual hasta prorratear los bienes del concursado entre sus acreedores.

En el derecho visigodo hay que mencionar la ley 5.6.5, debida a Chindasvinto, que regulaba la situación del deudor que contaba con varios acreedores; si aquél era solvente, se procedía al pago de la deuda por orden de solicitud o bien por la cuantía de los créditos, de mayor a menor, si todos los hubiesen pedido simultáneamente. Si

\footnotetext{
${ }^{17}$ Fritz Schulz, Derecho Romano Clásico, Barcelona, 1960, pp. 290-291.
} 
los bienes del deudor eran insuficientes para atender a todos sus acreedores se hacía entrega de su persona a los no satisfechos, entrando así en una suerte de prisión-servidumbre. En la ley 2.5.8 se condenaba al deudor con un solo acreedor no a la prisión sino al pago de duplo al triple de la cantidad adeudada.

Ya en época medieval se procede al encarcelamiento del insolvente, con lo que se perseguía tanto el castigo del deudor como el coaccionarle al pago. En los fueros municipales plenomedievales se distinguían tres clases de aprisionamiento: la prisión como garantía de comparecencia en juicio, la del deudor manifiesto y vencido en juicio y la de la mujer e hijos del deudor. En el mal llamado Derecho territorial se contempla una sustitución parcial de la prisión por deudas por otras medidas, como el asentamiento de bienes o la ejecución patrimonial forzosa.

En el Fuero Real se contempla la prisión del insolvente (3.8.2) y el pago a los acreedores (3.30.5): aquél quedaba liberado, tras haber minorado los créditos hasta satisfacer a todos los acreedores. Las Partidas aceptan el asentamiento de bienes y la ejecución patrimonial, hasta poder decirse que ésta será la habitual; introduce así mismo la cesión de bienes (5.15.1), así como la prisión del deudor (prisión-coacción) a fin de obligarle a presentar dicha cesión (5.15.4); una vez hecha ésta, el deudor quedaba liberado. En el ordenamiento de Sevilla de 1360, de Pedro I, en su ley 19 se reforma la mencionada ley 5.6.5 de Chindasvinto en el Liber: como principio general determinaba que nadie fuera preso por deudas, si bien establecía numerosas excepciones; el fallido debía jurar sobre los Evangelios que abonaría la deuda en cuanto estuviera en condiciones de hacerlo.

El siguiente paso vino dado por Enrique IV, en las Cortes de Madrid de 1458, que estableció que, realizada la cesión de bienes sin haber satisfecho todos los créditos, el deudor fuese entregado sucesivamente a sus acreedores para que les hiciese pago con su trabajo. Bajo los Reyes Católicos se aprobarán seis pragmáticas sobre temas de insolvencia: obligación del deudor que hubiera hecho cesión de bienes de llevar la argolla al cuello (26/07/1490), no validez del acogimiento en sagrado para los deudores (14/05/1498), cesión de bienes automática tras estar seis meses en prisión (18/10/1501), revocación del privilegio de Sevilla, de no ser presos por deudas los que mantuvieran caballo año y día (08/06/1501), obligación de hacer entrega del deudor a los sucesivos acreedores, sin dejar de llevar la argolla (12/02/1502), y castigo como ladrones a los mercaderes y cambiadores que se alzasen (09/06/1502) —revalidada en las Cortes de Madrid de 1537 y luego en pragmática de 1590-.

En el reinado de Felipe II se aprobaría la ley de 1566 (N.R. 4.21.19), que establecía, en primer lugar, la ejecución de los muebles, dando fiador de saneamiento, so pena de ceder bienes y renunciar la cadena; el capítulo de Cortes de 1592, por el que se establecía que sólo se dictase una sentencia de graduación por instancia, ${ }^{18}$ y la men-

\footnotetext{
${ }^{18}$ Se estimaba que, de no limitarse la sentencia de graduación a la definitiva de la instancia, se actuaba maliciosamente, con la finalidad de perjudicar a los acreedores, siendo estos pleytos que de ordinario
} 
cionada pragmática de 18/07/1590, por la que el deudor que pretendía se le concediese espera o hacer cesión de bienes estuviese en prisión hasta saberse de su solvencia. ${ }^{19}$

\section{Procesos ejecutivos en la época moderna}

Basaba el profesor Alejandre, con acierto, su exposición sobre la quiebra en el derecho español sobre dos pilares, la cesión de bienes, recibida a través de las Partidas, y la quiebra propiamente dicha, que alcanzaría su máxima expresión en las Ordenanzas del Consulado de Bilbao de 1737.

Sin dejar de ser cierto esto, hoy es posible añadir muchos más elementos a este proceso, gracias a la existencia de una gran cantidad y variedad de fuentes, desconocidas en décadas pasadas, máxime si nos desprendemos del prejuicio de que se dio una neta separación entre el concurso de acreedores y la quiebra. Para ello pretendo hacer una breve exposición de algunos procesos característicos, que servirá para conocer la complejidad que se dio en los siglos XV y XVI en las soluciones legales y judiciales a la hora de resolver las situaciones de insolvencia; a partir del siglo XVII se creará el paradigma del concurso castellano de acreedores, válido para concursados tanto civiles como mercantiles, tal y como se recoge en las obras de Amador Rodríguez y Francisco Salgado de Somoza y que Cervantes denominará, como la mayoría de sus contemporáneos, «pleito de acreedores».

Los Consulados, hasta donde nos es posible conocer, ensayaron también sus soluciones, si bien el bilbaíno de los siglos XVII y XVIII utilizará para dar curso a las quiebras el mismo procedimiento concursal ya conocido; sólo a partir de los años

no tienen más dificultad de graduar a los acreedores por las datas de sus contratos, que es cosa que las más vezes no las sentencian los juezes, sino los escrivanos. Así se expresaban en las Cortes de 1592 (pet. 15), recordando que ya lo había solicitado así en la reunión de 1583.

En la petición 14 expusieron: Hase introduzido tanto hazer pleytos de acreedores, por dilatar los deudores el pagar, que demás de seguirse muchos gastos y costas, se fazen los pleytos inmortales, y estando los acreedores defraudados y suspensos de cobrar sus haziendas, aprovechándose dellas sus deudores. Suplicamos a V.M. mande que con la primera sentencia de graduación en el pleyto de concurso de acreedores, sean pagados según su antelación, dando fianças depositarias de restituyrle, si la tal sentencia se revocare.

A esto vos respondemos ser justo lo que se nos pide, con que se entienda en los pleytos de acreedores que en el nuestro Consejo, Chancillerías y Audiencias se sentenciaren en primera instancia o en segunda, confirmando o revocando la sentencia o sentencias dadas por los juezes ordinarios inferiores, que en tal caso sin esperar tercera sentencia de graduación y sin embargo de la suplicación que della se interpusiere, sean pagados los acreedores por su antelación, dando fianças depositarias de restituyr lo que assí cobraren, si la tal sentencia se revocare en grado de revista (Biblioteca de la Real Academia de la Historia, Pragmáticas, 4/641, $\left.\mathrm{n}^{\circ} 17\right)$.

${ }^{19}$ Premática para que los mercaderes y hombres de negocios y cambios públicos y sus fatores que trataren de hazer compromisos para remisión o espera de lo que devieren o hizieren pleyto de acreedores estén presos y no sean sueltos hasta que los pleytos se acaben y ayan dado fianças de pagar lo que deven, con que el plazo no exceda de cinco años (Alcalá de Henares, 1590; BRAH, Pragmáticas, 4/649, $\left.\mathrm{n}^{\circ} 29\right)$. 
previos a 1737 se aprecia un progresivo cambio, que cristalizará en un nuevo paradigma de quiebra, en sus ordenanzas consulares de ese año, que luego se extenderá a los demás consulados de España y la América hispana.

\subsection{La ejecución singular}

Como resulta lógico allí donde sólo existían un deudor y un acreedor la solución de la insolvencia de aquél no planteaba excesivos problemas. ${ }^{20}$ Los antecedentes medievales de este procedimiento cabe buscarlos en el Fuero Real (3.20.1), sin embargo, es en el ordenamiento dado por Enrique II a Sevilla (20/05/1369) donde se regula el proceso de ejecución sumaria para documentos con fuerza ejecutiva, más tarde reformado por Enrique IV (1458), añadiendo excepciones, por los Reyes Católicos (Toledo, 1480 y Madrid, 1502), Carlos I (Valladolid, 1548) y Felipe II (1560 y 1566). ${ }^{21}$

En cuanto a la tramitación, se seguían dos fases, la vía ejecutiva y la vía de apremio. Se iniciaba la primera a petición del ejecutor, que presentaba su título: comprobado el carácter ejecutivo del documento e inaudita la parte, se libraba auto de ejecución, dando mandamiento al alguacil (llamado en Cuenca ejecutor de fuero) para que trabase bienes suficientes para cubrir el principal y las costas. Alguacil y escribano comparecían ante el deudor, el cual podía presentar carta de pago o abonar la deuda; de no hacerlo, se intervenían bienes muebles y se ponían en depósito (de resultar ser insuficientes se procedía a la mejora de la ejecución, ampliándose los bienes trabados). Los bienes ejecutados se ponían en pública almoneda, previa petición del ejecutor, dictándose auto de pregones ( 3 pregones, en plazo de 9 días). Tras la correspondiente petición se procedía a la citación para remate, dándose ocasión al deudor para oponerse, presentando para ello los necesarios documentos probatorios. Se daba traslado a las partes, que presentaban sus alegaciones, terminando con el auto de conclusión, seguido de la sentencia de remate: se avivaba la voz de la almoneda, se hacía trance y remate de los bienes y se pagaba de su valor al acreedor, una vez constituida la fianza de la ley de Toledo, para el caso de que la sentencia fuera revocada.

La vía de apremio: satisfecha la fianza, se abría la posibilidad de que fueran presentadas nuevas posturas mediante la emisión del cuarto pregón, se presentaban posturas, produciéndose el remate, tras realizarse el justiprecio; solicitado el apremio, se pedía la tasación de las costas, dándose el apremio por las costas y el principal. Finalmente, el juez dictaba auto para que se hiciese tanto dicha tasación como el correspondiente apremio al deudor. En nuestros archivos se conserva un número ingente de ejecuciones singulares, por ser las más habituales. También era habitual que los concursos de acreedores forzosos se iniciasen mediante la acumulación de varias vías ejecutivas.

\footnotetext{
${ }^{20}$ Véase el citado artículo de Peláez Portales.

${ }^{21}$ Así pasará a la Nueva Recopilación, a la Novísima y a la Ley de Enjuiciamiento en causas comerciales (1830), hasta la Ley de Enjuiciamiento Civil de 1855; se separaba la ejecución de la sentencia de la ejecución de los restantes títulos, que llevaban aparejada ejecución.
} 


\subsection{Proceso de cesión de bienes, según disposición de Cortes de 1458}

Aunque es posible encontrar algunas provisiones reales sobre casos de insolvencia durante el reinado de los Reyes Católicos, uno de los pocos procesos de estas características que he localizado ha sido el que se siguió en Jaén, en 1506, contra Pedro Jiménez de La Guardia, hombre de negocios de la ciudad, al menos desde 1498; en 1503 se adjudicó el arrendamiento del sexmo de las minucias de la collación gienense de San Ildefonso; al no poder atender a sus acreedores, se alzó y huyó hacia Baena, donde fue apresado por uno de sus acreedores, que lo llevó de vuelta a Jaén. ${ }^{22}$

Una vez arrojado a la prisión, hizo cesión de bienes, declarando los nombres de sus acreedores, que fueron notificados. Al propio tiempo nombró procurador (no defensor ni depositario), para designar nuevos acreedores más tarde. Estos fueron compareciendo ante la justicia, presentando sus títulos. Acto seguido, se le asignaron alimentos; Pedro Jiménez reconoció unas deudas y negó otras. Finalmente, pasados algo más de dos meses desde su entrada en prisión, se dictó sentencia: se comenzó por declarar como bien hecha la cesión de bienes, luego se concedió preferencia en el cobro al acreedor que se había tomado la molestia de apresarlo ${ }^{23}$ y se ordenó echarle la argolla al cuello, de acuerdo con la pragmática. Debería servirle en su oficio al acreedor preferente hasta hacerle ganar los $7.500 \mathrm{mrs}$. que le adeudaba —debiendo el acreedor alimentarle convenientemente-; saldada la deuda con éste, sería entregado al resto de los acreedores por su orden de graduación.

Unos consintieron la sentencia y otros apelaron, presentando los apóstolos.

Un proceso unos años anterior (1485-1487) nos informa sobre los litigios entre acreedores para hacerse con los servicios de los condenados a trabajar para ellos con la argolla al cuello. ${ }^{24}$ La causa la planteó Benito García odrero, vecino de Valladolid, contra el mercader Pedro de Portillo, de su misma vecindad, pues Fernando Cijuelo jubetero llevaba 10 meses sirviendo a éste y deseaba que pasase a trabajar para él, a fin de resarcirle por una deuda de 5.436 mrs. El doctor Martín de Ávila, oidor de la Audiencia y juez comisionado, había fallado que Portillo se diese por pagado por el tiempo que le había servido el jubetero y que ahora pasase a servir al demandante. Llevado el caso a la Chancillería, los oidores confirmaron en vista y revista la sentencia del comisario. ${ }^{25}$

\footnotetext{
${ }^{22}$ Archivo Histórico Provincial de Jaén, Justicia, leg. 4.495 (en mal estado). Preveo en un futuro próximo redactar un estudio más detallado sobre los orígenes del pleito de acreedores, donde desmenuzaré el contenido de este interesante y singular proceso.

${ }^{23}$ F.R. 3.20.12 y Partidas 5.15.10.

${ }^{24}$ Archivo de la Chancillería de Valladolid, Reales Ejecutorias, 8/26.

${ }^{25}$ Algunos años después (1513-1517) era Antón de Jaén, cambiador granadino, el que estaba preso y encarcelado en esa ciudad por deudas que le reclamaba el maestre Enrique Egas, en su calidad de maestro mayor de las obras de la Capilla Real; Antón señaló como deudor suyo al comendador Fernando Ramírez Galindo, hijo del artillero Ramírez de Madrid y de Beatriz Galindo - para la que el chico fue una au-
} 


\subsection{El proceso de aceptación de bienes en pago a tasación}

Este tipo de procesos sólo se ha localizado en Cuenca —en los archivos provincial y diocesano-, donde, al igual que en Segovia, el desarrollo fabril del siglo XVI propició la aparición de una documentación bastante original referente a estos temas.

Uno de ellos se dilató en la capital conquense entre 1578 y 1619; el carpintero Jerónimo de Vadillo, acosado por sus acreedores, hizo cesión de sus bienes ante la justicia; tras realizarse la correspondiente estimación y tasación de los mismos, el actor solicitó al corregidor que obligase a comparecer ante él a sus acreedores para que concurriesen a la adjudicación de los mismos, de acuerdo con sus prelaciones y anterioridades y los tipos de títulos que documentaban sus créditos, todo ello según la tasación ya cerrada. De no concurrir los acreedores a comprobar la tasación, el corregidor procedía a aprobarla, ordenando los créditos y procediendo a la adjudicación en pago. ${ }^{26}$

Se trataba de un privilegio para el deudor, de ahí la habitual resistencia de los acreedores a comparecer a recibir en pago unos bienes en los que probablemente no estaban interesados. De hecho, había habido una sentencia anterior del corregidor, que fue apelada por los acreedores ante la Chancillería de Granada, que dio su ejecutoria

téntica pesadilla-; Egas pudo perseguir con éxito su sueldo por la tenencia de Salobreña, pero no sus bienes raíces (la Huerta del Darro, junto al actual Paseo de los Tristes, y el mesón y cortijo de Deifontes) (Archivo Histórico Nacional, Sección Nobleza, Bornos, leg. 1.546, signatura antigua; actual 406/2).

Probablemente, el proceso de este tipo más antiguo conservado sea el que tuvo lugar en Zorroza (Vizcaya) entre julio y octubre de 1467, contra el matrimonio formado por Pedro Martínez de Elorriaga y doña Sancha Sánchez de las Ribas, vecinos de Bilbao, que fueron ejecutados por varias obligaciones, siendo finalmente enajenadas sus veneras y heredades (Javier Enríquez Fernández, Concepción Hidalgo de Cisneros y Adela Martínez Lahidalga, Colección documental del Archivo Histórico de Bilbao (13001473), Fuentes documentales medievales del País Vasco, 90, San Sebastián, 1999, doc. 96, pp. 356-393).

Para fines de 1532 Diego de Herriega, hombre de negocios de Uclés, arrendatario de las rentas del convento de Santiago, sito en dicha villa, entró en insolvencia, razón por la que el procurador del prior solicitó al Consejo de Órdenes que mantuviera su derecho a salvo frente a otros acreedores (Diego de Herriega, vezino de la villa de Uclés, fue arrendador de las rentas del dicho convento los años pasados de quinientos e veynte e nueve e treynta e treynta e un años, del qual dicho arrendamiento quedava a dever más [de] ochocientas mill mrs., por las quales el dicho convento, mi parte, le tiene hecha execución asi en los bienes propios del dicho Diego de Herriega, como en los frutos e diezmos y décimas de los dichos tres años, qu'están tácita y expresamente obligados al dicho convento, mi parte. E agora sabrá V.M. que algunas personas se oponen a querer tomar e ocupar los dichos frutos de las dichas décimas y hazienda de los dichos tres años, lo qual es en grand perjuizio del dicho prior y convento, mi parte, por tanto a V.M. pido y suplico mande dar su provisión para que, pues el dicho convento, mi parte, es primero en tienpo e mejor en derecho, que ninguna persona se entremeta a ocupar ni enbargar ni cobrar las dichas décimas e hazienda del dicho mi parte hasta que realmente e con efeto el dicho convento sea pagado, e, si alguna persona pretendiere derecho a los bienes y hazienda del dicho Diego de Herriega, se lo pidan e demanden). El Consejo se limitó a encomendar al gobernador del partido de la Mancha que conociese del caso, mediante la correspondiente incitativa (Archivo Histórico Nacional, Órdenes Militares, Archivo Histórico de Toledo, leg. 78.191; provisión de 13/11/1532).

${ }^{26}$ Archivo Histórico Provincial de Cuenca, Sección Judicial, 25/1 (proceso amplísimo e incompleto). 
(24/09/1578), confirmatoria de la sentencia de la anterior instancia, obligando a los acreedores a concurrir a la asignación de los bienes cedidos.

Pasados dos siglos, volvemos a encontrar otro de estos expedientes en Vizcaya: en 1799 Miguel de Aqueche, vecino de la anteiglesia de Lejona, por cuanto no tenía bienes para satisfacer a sus acreedores y considerando que la formación de un concurso a ella - la casería de Bidaurrazaga, su única propiedad- había mucho dispendio de costas y gastos, para evitarlos y el que también sus acreedores no le molesten con diligencias judiciales, ha resuelto proponerles como desde luego les propone pagarles en tierras de la misma casa o montes a tasación de maestros ynteligentes. ${ }^{27}$

\subsection{La espera: acuerdos privados, expedientes y procesos}

Cuando una persona se encontraba en una situación temporal de insolvencia era normal que intentase obtener una espera de sus acreedores. Cabían tres posibilidades: alcanzar un acuerdo privado entre las partes, de lo cual queda testimonio frecuentemente en los protocolos notariales; ${ }^{28}$ conseguir una concesión graciable de la Corona o litigar contra los acreedores para que se la concedieran.

Así mismo, podía pactar una especie de salvoconducto con los acreedores, como el que celebró en 1561 entre el capitán Antonio de Urtendona, en nombre propio y de su familia, con los que tenían créditos contra ellos, todos bilbaínos. ${ }^{29}$

Ya en Partidas (5.15.5 y 6) se contemplaba la posibilidad de establecer dichas esperas, siendo reguladas más tarde por Enrique IV en sus Cortes de Santa María la Real de Nieva de 1473 (pet. 30); según esta disposición, las esperas reales deberían

\footnotetext{
${ }^{27}$ Finalmente, se acuerda que Aqueche quedase libremente con la mitad de la propiedad, dejando la otra mitad a inquilino, de cuyas rentas fuesen pagados los acreedores, es decir, acaba como un allanamiento (Archivo Histórico Foral de Vizcaya, Sección Judicial, Corregimiento, 379/14).

${ }^{28}$ A primeros de julio de 1553 Martín Gómez, por cuanto san Juan de Segura zapatero, ambos vecinos de Castro Urdiales, le adeudaba 16 ducados en virtud de un conocimiento de plazo pasado, por ende, que él de su propia boluntad hera contento d'esperar e azer espera de los dichos dizeséis ducados y paga dellos al dicho san Juan de Segura por tienpo y espacio de dos años, que corren e se quenten desde oy día de la fecha, e que durante el dicho tienpo no se los pidirá ni demandará en juizio ni fuera d'él, so pena de perderlos; obligó persona y bienes y dio poder a los jueces para ello (Archivo Histórico Provincial de Cantabria, Protocolo 1.707, fol. 501).

${ }^{29}$ Como no podía hacer frente a sus deudas, e por temor que no fuese preso y bexado y afrentado de su persona, avía estado y está ausente de esta tierra de cierto tienpo a esta parte, pero deseaba pagarles, los acreedores se obligaron a no importunarle en modo alguno durante 3 meses, para que pudiera acercarse a Bilbao y alcanzar con ellos un acuerdo (AHFVizcaya, Sección Judicial, Corregimiento, 845/90).

Esta práctica, sin embargo, era muy anterior, como se documenta en el Jaén de fines de 1491, cuando el jurado Diego Sánchez del Corral aseguró al mercader Juan Fernández de Baeza, huido de la ciudad por deudas, para que pudiese entrar en ella durante 12 días, comprometiéndose a no reclamarle los 12.000 mrs. que le debía en virtud de una obligación (AHPJaén, Protocolo 2, fol. 29r).

En las quiebras bilbaínas posteriores a 1737 es un elemento habitual, con la finalidad de que el quebrado pudiera negociar con la junta de acreedores sus acuerdos de quita y espera.
} 
concederse por un máximo de 2 años, previa información realizada por el Consejo real para averiguar las posibilidades económicas de las partes. En el Archivo de Simancas se conserva abundante documentación sobre estas esperas, en la sección correspondiente a dicho Consejo. ${ }^{30}$

Un ejemplo de estas esperas regias se produjo a fines de agosto de 1577 cuando se encargó información a la justicia sobre la petición presentada por diversos vecinos de los pueblos conquenses de La Melgosa y La Olmedilla, que no podían pagar a los que les habían suministrado trigo y paños en los últimos tiempos a causa de la esterilidad habida entonces. ${ }^{31}$

También cabía la posibilidad de que el deudor demandase a sus acreedores para que le concediesen dicha espera; así, en Cuenca, en 1569, documentamos al curtidor Hernán López que demandaba a sus tres acreedores para que le permitiesen dilatar el pago de sus deudas, una vez que había llegado a un acuerdo en ese sentido con su principal acreedor; para ello presentó ante el juez la obligación que documentaba la deuda con éste con el escrito de la espera concedida. ${ }^{32}$

Se trataba, pues, de un privilegio del deudor, sustanciado a través de un juicio declarativo ordinario. Abundan este tipo de procesos en el archivo provincial de Cuenca y en el municipal de Úbeda.

Resulta significativo que así como la espera es algo bien documentado en la práctica bajomedieval y moderna, no lo sea la quita; aunque también prevista en la legislación justinianea (C. 7.71.8), ${ }^{33}$ apenas aparece en la documentación consultada, tan sólo en algún caso aislado, ${ }^{34}$ como el mencionado concurso de Larrauri; también se

${ }^{30}$ Valga como ejemplo de las existentes en los fondos de Simancas la espera concedida por los Reyes Católicos, a fines de 1483, por un año al mercader genovés Cristóbal Grimaldo, residente en Sevilla, contra otros colegas compatriotas suyos y burgaleses (Archivo General de Simancas, Registro General del Sello, 26/11/1483, fol. 45).

Cariz distinto presenta la incitativa dada por los mismos monarcas al corregidor de Segovia a mediados de 1480, a petición de Elvira González, sobre los malos tratos y prisión propinados a su marido, Alfonso González, por sus acreedores, a quienes no podía contentar por haber sido robados sus bienes por la rebelde condesa de Medellín (Idem, 03/06/1480, fol. 90).

${ }^{31}$ AHPCuenca, Sección Judicial, 23/16. Se trata del expediente informativo realizado en virtud de la provisión del Consejo; los acreedores se opusieron, frente a los deudores que alegaban que ellos eran pobres y sus oponentes, ricos.

${ }^{32}$ AHPCuenca, Sección Judicial, 14/2. La sentencia en este caso fue denegatoria. Más afortunado fue Juan de Monteagudo, quien en 1585 obtuvo de Gregorio de Santander y sus demás acreedores una espera de 6 años, tras litigar durante cinco meses ante el corregidor de Cuenca, de donde eran todos vecinos (AHPCuenca, Sección Judicial, 33/10).

${ }^{33}$ Guillermo F. Margadant opina que esta constitución de Justiniano sólo se refiere a la espera, pero no a la quita («'La espera’ en la segunda vida del Derecho Romano», Estudios en homenaje a Jorge Barrera Graf, México, 1989, II, p. 1.065).

${ }^{34}$ En 1591 Marina de Iruxta, mujer de Andrés Beoliz, francés, residente en Bilbao, alcanzó un acuerdo de quita y espera dentro del concurso de su marido, huido de los Reinos de Castilla; uno de los acreedores se mostró contrario al acuerdo, alegando pragmática [sic] de Córdoba de 1570, que impedía celebrar convenios con mercaderes quebrados, retraídos en sagrado o huidos del Reino. Finalmente el acuerdo 
la ve integrada en algunos pleitos de acreedores del siglo XVI y, desde luego, es habitual en las quiebras bilbaínas posteriores a 1737 .

\subsection{El concurso de acreedores}

Como decía, antes de que cristalizase el modelo de concurso de acreedores recogido en la literatura jurídica del siglo XVII, los tribunales tuvieron que buscar soluciones imaginativas a los problemas que se les iban presentando; para ello contaban con la vía ejecutiva, que se volvía inaplicable cuando eran varios los que reclamaban el pago de sus créditos, así como con el juicio declarativo ordinario, además de con la consabida cesión de bienes.

Dos ejemplos tomados de los riquísimos fondos judiciales segovianos pueden ilustrarnos sobre lo que venía ocurriendo en los tribunales de la primera mitad del siglo XVI cuando se enfrentaban a juicios concursales.

Entre 1547 y 1553 se planteó pleito de acreedores de carácter forzoso: Mari Calva, vecina de Segovia y mujer de Juan García merinero, compareció ante la justicia para exponer que su marido se había alzado y para demandar protección para sus bienes dotales. ${ }^{35}$ Exigía que fuese considerada acreedora preferente; convocados los demás acreedores, litigaron entre sí, como en un juicio ordinario; finalmente, se valoraron los bienes conocidos, todos inmuebles, y se dictó sentencia, siéndole adjudicados a la esposa el total del valor de su dote y el resto se entregó a los demás acreedores, a fin de que cobrasen de acuerdo con sus prelaciones. ${ }^{36}$

Poco después, en 1556, se planteó otro pleito de acreedores, con carácter voluntario, pues Alonso Redondo, vecino de Zamarramala, acudió al juez para hacer cesión de bienes en sus acreedores, presentando para ello relaciones de bienes y deudas. Acto seguido, su mujer, Catalina de Cubillo, se opuso por sus dotales, pidiendo preferencia en el pago; también comparecieron distintos acreedores. En la sentencia de graduación se declaró que primero cobrase la mujer, pero, si no hubiera bienes suficientes para cubrir su dote y arras, se le entregase el cuerpo del marido hasta que abonase la diferencia con su trabajo; luego sería cedido a los demás acreedores con el mismo fin, según el orden de sus prelaciones. ${ }^{37}$

Leyendo estos procesos no puede dejarse de tener la impresión de que se trataba de arreglos entre los esposos para burlar a sus acosadores crediticios. Una sensación

alcanzó sanción judicial en primera instancia, si bien no se conserva la sentencia del juez mayor de Vizcaya, en la Chancillería (ARChValladolid, Pleitos de Vizcaya, 823/8).

${ }^{35}$ Más contundente en su denuncia fue la gienense María de la Cueva, en 1588, respecto de su marido, Pedro Rodríguez de la Oliva, el cual por culpa suya a benido a quiebra y muncha diminución, por ser como a sido pródigo y disipador de sus propios bienes, de modo que corría el riesgo de quedarse sin sustento, al perder dote y arras (AHPJaén, Justicia, 4.495)

${ }^{36}$ Archivo Histórico Provincial de Segovia, Sección Judicial, J-1.400 (procesos sin numerar dentro de cada caja).

${ }^{37}$ AHPSegovia, Sección Judicial, J-1.400 (en mal estado). 
parecida causan los procesos por quiebras del Consulado de Bilbao, en este caso por la connivencia entre las autoridades consulares y los quebrados, que podían serlo alternativamente.

En cualquier caso, de acuerdo con la experiencia segoviana, parece claro que se extendió la práctica de la huida del mercader, dejando a la mujer a cargo de salvar lo posible del negocio familiar reclamando sus dotales y quedando burlados los acreedores reales. ${ }^{38} \mathrm{Si}$ no se actuaba de ese modo, lo habitual era que se fuesen acumulando las vías ejecutivas contra el deudor, que acababa en prisión y concursado, si bien siempre cabía el recurso de la mujer a pedir el abono de su dote, lo cual sólo era de recibo hacerlo una sola vez. Por lo que se refiere al proceso voluntario, solía provenir de una actuación del concursado o bien de sus herederos; en los concursos conservados en Cantabria se aprecia cómo muchas pequeñas explotaciones agrarias llevaban una penosa existencia económica, pagando corridos por censos en ocasiones muy antiguos, sin esperanzas de poder redimirlos; tarde o temprano la muerte del propietario de la explotación ponía a sus herederos ante la disyuntiva de cargar con un pesado pasivo o liquidar la herencia paterna. En este último caso, los herederos aceptaban la herencia con beneficio de inventario o, mejor, la repudiaban y ejercitaban la cesión de bienes. ${ }^{39}$

${ }^{38}$ A mi modo de ver, en la generalización del «pleito de acreedores» tuvo mucho que ver este tipo de trapisondas, aunque no siempre era así: entre 1568-1572, por ejemplo, tuvo lugar el concurso del salmantino Francisco de Ribas, nombrado oidor de la Audiencia de Quito, el cual falleció a los pocos días de llegar a Panamá — el qual desde a pocos días de como llegó a esta cibdad, adoleció e como la tierra es malsana, aunque su enfermedad paresció a los principios libiana, fuele faltando la virtud, e ansí murió a los diez de agosto deste año (1567)—, rumbo a su destino; en 1551 Juan Montero mercader y su mujer, también salmantinos, otorgaron dote a su hija, Catalina de Sena, que iba a desposar al letrado, por valor de 3.000 ducados; Ribas le prometió arras, de acuerdo con lo establecido, de 300 ducados. Fallecido el oidor, Montero, en nombre de su hija, reclamó el reintegro de dote y arras (Archivo de la Real Chancillería de Valladolid, Fernando Alonso (F), 96/02).

${ }^{39}$ En ocasiones la cesión de bienes se produjo de manos de los albaceas, caso de las testamentarías: entre 1718 y 1729 tuvo lugar el concurso de acreedores de los bienes del difunto don Laureano Sagredo Manrique, en Madrid: el teniente de Corregidor comunica a las justicias del Reino que se había hecho tasación de los bienes dejados por el fallecido, resultando ser insuficientes para cubrir todo el pasivo conocido, habiendo acreedores siguiendo sus vías ejecutivas en perjuicio de otros con mejor derecho, de modo que el albacea decidió ejercitar la cesión, abriendo el juez concurso universal (Archivo Histórico Regional de Madrid, Familias Nobles, 5.297/4, 269 folios).

Muy cercanos a esos expedientes estaban los juicios de abintestato, como el que tuvo lugar en Villamanta (Madrid) entre 1789-1790, en cabeza de María Rodríguez, mujer de Pedro Sánchez, abastecedora de la tienda pública de la villa; finalmente fue sucedida por sus 4 hermanos, que solicitaron que se sustanciase el caso sin tela de juicio, en lo que contaron con la anuencia del conde de Campomanes (ARCMadrid, Villamanta, 3/60, caja conteniendo procesos diversos). O el que se siguió contra los bienes dejados por Manuel de Salcedo Ordóñez, cura difunto de Leiva (La Rioja) en 1707-1740 (Archivo Histórico Provincial de Logroño, J-702/2 y J-738/22).

También lo estaban los autos de inventario y distribución de bienes, como los habidos en aquella villa entre los acreedores del difunto Jacinto Marina, en 1800-1801 (ARCMadrid, Villamanta, 3/60). 
Esto es lo que ocurrió en el barrio de Ceceño del concejo del Tejo (Valle de Valdáliga) en 1765; ${ }^{40}$ el 15 de abril Josefa, Ana y Antonia, hijas de Andrés Bracho, recién fallecido, viudo de María Vélez, se presentaron ante la justicia para hacer cesión de los bienes recibidos en herencia de Andrés y de Tomás Bracho, su hermano y tío de las cedentes.

Actuó de juez de la causa don José Gómez de la Riva, presbítero, beneficiado de San Martín de Rubiales, en el obispado de Osma, vecino de Comillas, en su calidad de juez de comisión por el obispo de Santander para el reconozimiento y reintegro de la obra pía de Escuela el lugar del Tejo. Ante el escribano Francisco Antonio de la Torre Trasierra.

Para ello aportaron dos detallados memoriales, uno de bienes ${ }^{41}$ y otro de deudas, incluyendo los nombres de los acreedores y las cantidades que les eran adeudadas. ${ }^{42}$ Hecha la petición de que fuese admitida la cesión, el juez dictó auto de aceptación de la misma, con lo que se abría concurso universal; con ello los deudores quedaron liberados de responsabilidad.

Acto seguido fueron nombrados depositario y defensor de los bienes ${ }^{43}$ para ello se les notificó a ambos si aceptaban el encargo, aceptado el cual, prestaron juramento

${ }^{40}$ AHPCantabria, Alfoz de Lloredo, 51/5. Este concurso se extendió durante 8 meses sólo y no causó ningún incidente; podría decirse que es el típico concurso de acreedores en esencia. Tiene, desde luego, la peculiaridad de que el caudal alcanzó para pagar todas las deudas y derechos, quedando un exiguo remanente.

En el extremo opuesto, en cuanto a su complejidad, se localiza en la misma sección el concurso de doña Manuela de Ortegón, viuda de Pedro Ildefonso de la Torre, encarcelada, vecina de Comillas y comerciante (1798-1801), que acabó por hacer cesión de bienes a instancias de los comerciantes bilbaínos José Antonio de Olabarría, la viuda de Learreta y Ramón Antonio de Urcullu, marido de doña María Sebastiana de Goitia, que la acusaban de simular concurso; la cedente es amonestada a que dijera más verdad en sus escritos; la Chancillería interviene en varias ocasiones, todo ello a lo largo de 237 folios (AHPCantabria, Alfoz de Lloredo, 52/1).

${ }^{41}$ Formaban el caudal una casa en pie y otra caída y 26 piezas de tierra y prado en distintos lugares, en su mayoría de escasos carros de tierra.

${ }^{42}$ Los bienes estaban gravados con seis censos y resto de un impagado de 88 reales por la administración de la hacienda de los padres de Josefa del Castillo, vecina de San Vicente de la Barquera. Los censos eran éstos:

— censo a favor de la luminaria del Santísimo Sacramento de la iglesia de Revilla (27/04/1659).

- censo a favor de Francisco Gómez de La Mata, vecino de Treceño, familiar y notario del Santo Oficio, y su mujer (05/04/1671).

- censo a favor de la capellanía fundada en Revilla por Juan Francisco de la Mara Valdés, fallecido en Indias (18/08/1683).

— censo a favor del Hospital de la Misericordia de San Vicente de la Barquera (06/04/1693).

— dos censos a favor e la obra pía de la escuela del Tejo, fundada por Tomás Díaz de Lamadrid $(25 / 09 / 1695$ y $14 / 11 / 1698)$.

Todos presentaron los documentos originales, salvo el responsable de la luminaria, que aportó certificado notarial, que le fue admitido.

${ }^{43} \mathrm{Si}$ los herederos hubieran sido menores - lo que era habitual en estos casos-, hubiera sido preciso discernir un curador ad litem. 
de cumplirlo fielmente. Asegurados los bienes en concurso de este modo, se procedió a notificar la apertura del concurso a los acreedores conocidos, fijándose el primer edicto, con notificación al defensor y a los acreedores (a éstos en los estrados); así mismo se libró el correspondiente requerimiento. A petición del defensor se mandó fijar el segundo edicto, dictándose auto de fijación y notificacion, como se hizo de nuevo con el tercer edicto.

Hasta ahí la fase inicial (16 de mayo); sin embargo, entre el segundo y tercer edicto ya habían comparecido a oponerse al concurso los titulares del censo de 1671.

Comenzaba entonces la segunda fase: la de concurrencia de los acreedores, equivalente a la fase de probanzas en el juicio ordinario. Uno tras otro fueron compareciendo los tenedores de los censos, para presentar el documento original - que quedaba incorporado al proceso - y la petición de ser admitidos al concurso. En todos los casos el juez dictó auto de admisión, aun en el caso de no exhibirse el contrato original. Como todos los autos, se notificaba al resto de las partes. Éstas solían alegar sobre quiénes debían ser preferidos, por sus prelaciones y antigüedades, cebándose habitualmente contra aquellos créditos no debidamente documentados.

El defensor del concurso, en efecto, presentó petición para que se declarasen libres los bienes de deuda no documentada convenientemente. Ante esta eventualidad, el juez libró auto dando traslado a las partes, que fueron notificadas, señalándose tres rebeldías y dictándose tras la última auto para proveer, auto que fue asesorado: por el mismo se recibió a prueba a las partes. El defensor concluyó para definitiva, sin presentar más probanza; tras las tres rebeldías, con sus notificaciones, se libró auto declarando por concluso el término probatorio y, acto seguido, el auto de conclusión para definitiva (12 de julio).

Se abría, así, la tercera fase, la del fallo: el 9 de septiembre, desde Comillas, el juez hizo pública su sentencia de graduación, asesorada. En la misma, se declaraba, en primer lugar, haber habido lugar la formación del concurso y haberse sustanciado éste legítimamente; a continuación mandaba tasar los bienes por peritos nombrados por las partes, so pena de designar el comisionado tercero en discordia de oficio. Acto seguido esos bienes debían ser sacados a pública subasta y rematados en el mejor postor. Si no se presentasen posturas arregladas — cosa relativamente habitual—, se debería pagar a los acreedores a tasación, esto es, adjudicándoles los bienes concursados de acuerdo con la cuantía de sus créditos. Seguía el establecimiento del orden de pago: primero, las costas y gastos de justicia, ${ }^{44}$ y luego los censos por orden de

\footnotetext{
${ }^{44} \mathrm{El}$ orden habitual era el siguiente: las costas y gastos judiciales, la dote de la esposa, las deudas privilegiadas, las hipotecarias y las quirografarias, y dentro de cada capítulo por la antigüedad de cada una. Los títulos de crédito presentados variaron de un siglo a otro, así en el siglo XVI, época en que predominó la economía productiva, los créditos se documentaban en escrituras de obligación, conocimientos o cédulas de cambio; en los dos siglos siguientes, cuando se despliega una economía crediticia, de rentistas, los títulos, como en el caso que nos ocupa, suelen ser censos consignativos. Naturalmente, en las quiebras ante Consulado se mezclan ambos tipos de títulos.
} 
antigüedad. ${ }^{45}$ Hecho el pago o adjudicación en dicho orden, se establecía la venta judicial, prohibiendo inquietar a los nuevos propietarios.

Dicha sentencia fue notificada a los acreedores en los estrados y al defensor en su persona.

El 13 de octubre comenzó la cuarta y última fase del procedimiento, la ejecución de la anterior sentencia; para ello el juez dictó auto de nombramiento de peritos tasadores por las partes, las cuales no lo cumplimentaron, de modo que el propio juez designó a tres vecinos de la localidad como medidores-tasadores. Notificado el nombramiento a éstos, aceptaron y juraron actuar imparcialmente. El escribano del tribunal les hizo entrega del memorial de bienes. Realizada su misión, los tasadores presentaron la memoria de los bienes tasados con su avalúo: llevaba fecha de 26 de noviembre y valoraba el total del activo en 7.395 reales de vellón.

El paso siguiente fue fijar edicto en la parroquia del pueblo con los bienes a subastar, expresando fincas y linderos; esto se hizo a las 9 de la mañana del día 8 de diciembre. A las 12 de esa misma mañana se realizó la diligencia de remate, sin que se presentasen pujas. No habiendo postores, el día 16 de diciembre se procedió a la liquidación de los bienes, teniéndose en cuenta tanto los principales como los réditos de los censos, además de los derechos y peticiones del defensor, las peticiones de las partes y los derechos del asesor, del escribano, de los tres peritos y del juez - que renunció a ellos en beneficio de los acreedores- $-{ }^{46}$ También se tuvieron en cuenta los 88 reales debidos a doña Josefa del Castillo.

El día siguiente se hizo pago a los acreedores por su graduación, recibiendo cada uno de ellos fincas por el valor de sus créditos; el activo alcanzó para pagar a todos los acreedores, además de las costas y tasas, sobrando un remanente de 36 reales y 23 mrs., que fueron puestos en depósito en manos de un vecino de Ceceño, hasta nueva orden. Esto se realizó el día 19, dándose así por cerrado el concurso.

Contra la sentencia de graduación cabía apelar ante la correspondiente Chancillería, sin embargo, apenas se han encontrado testimonios de esto entre los procesos conservados, no así en los que fueron apelados ante los diversos Consejos.

\footnotetext{
${ }^{45}$ Tras las costas y gastos:
}

$2^{\circ}$ ) la luminaria de la parroquia de Revilla, 10 ducados.

$3^{\circ}$ ) al censo de Francisco Gómez de la Mata, 15 ducados.

$4^{\circ}$ ) al censo de la obra pía del Hospital de la Misericordia, 40 ducados.

$5^{\circ}$ ) al censo del representante de don José Udías, 120 reales.

$6^{\circ}$ ) al censo de Tomás Díez, 20 ducados. En el mismo grado, la misma cantidad a la obra pía de la Escuela del Tejo.

$7^{\circ}$ ) En séptimo y último lugar se haga pago a doña Josepha del Castillo por su crédito de los bienes sobrantes después de estar enteramente satisfechos los referidos censos y sus réditos devengados, según la graduazión expuesta, y evacuados dichos pagos a los acrehedores de dichos vienes o postores en quienes se remataron, se les despache título de pertenencia y venta judizial, poniéndolos en posesión de ellos, con la pena de fuerza pública al que en ella los inquiete.

${ }^{46}$ Peticiones y derechos alcanzaron los 514 reales, llevándose la mayor parte el escribano (390 reales). 


\subsubsection{Concursos especiales: nobleza y concejos}

Por razón de la personalidad del concursado existían procesos que diferían en poco de los que se seguían con respecto al común de los sujetos, físicos y jurídicos.

Para el caso de los miembros de la nobleza, no parece que se les aplicara privilegio alguno, ${ }^{47}$ salvo la costumbre habitual de atribuirles alimentos que les asegurasen el mantenimiento de su alto nivel de vida, así como la intangibilidad de sus bienes vinculados. De hecho, los concursos nobiliarios, a veces prolongados durante muchas décadas, revisten más el aspecto de una administración judicial de sus haciendas que el de un concurso corriente. Por ejemplo, en el caso del concurso seguido a la Casa de Alcañices, ${ }^{48}$ los administradores nombrados por el juez se dedicaban a ir haciendo pago, según la liquidez disponible en cada momento, a los distintos acreedores, sin que fuera óbice la formación del concurso para que se fueran contrayendo nuevas deudas, de modo que estos procedimientos se volvían interminables. ${ }^{49}$ Da la impresión de que la nobleza castellana, poco persuadida del interés de los principios de la economía doméstica — gastar menos de lo ingresado-, vivía cómoda la vida de concursada, dejando que otros administrasen sus bienes, mientras pudieran mantener las apariencias. No obstante, generalizar estas características, de acuerdo con el profesor Domínguez Ortiz, ${ }^{50}$ a toda la nobleza de Castilla requerirá de estudios más detallados, evaluándose cuántas casas nobiliarias castellanas participaron y cuánto tiempo vivieron concursadas. ${ }^{51}$

\footnotetext{
${ }^{47}$ Sin embargo, se usaban distintos subterfugios, que fueron anulados por Carlos III por cédula de 1784, firmada de don Pedro Escolano de Arrieta; en la misma declaraba que eran notorios los perjuicios que las clases poderosas, distinguidas y privilegiadas causaban a los artesanos, porque sin atemperarse a sus rentas tomaban al fiado las obras y artefactos y dilataban la paga valiéndose muchos del fuero militar y otros que gozaban, o de ser Grandes y Títulos, lo qual cedia en la ruina de muchas familias de estos menestrales y en perjuicio del público (Madrid, 1784; Archivo Municipal de Burgos, HI, 5.663). ${ }^{48}$ El marquesado de Alcañices estuvo concursado entre 1607 y 1828 (Archivo de la Casa Ducal de Alburquerque (Cuéllar), Alcañices, Inventario 47, $\mathrm{n}^{\circ} 3$ y otras muchas piezas). En realidad, la situación de insolvencia arranca de 1553, cuando la marquesa casó, sin licencia real, con Álvaro de Borja, uno de los seguidores del duque de Gandía, siendo sus bienes embargados; en tiempos sucesivos sus descendientes mantendrán numerosos litigios por la sucesión del título (Idem, $\mathrm{n}^{\circ} 63 \mathrm{~B}$, leg. 14, $\mathrm{n}^{\circ} 52$ ).

La Casa de Alburquerque, así mismo, estaría bajo concurso, al menos, entre 1578 y 1668 (ADCA, Alburquerque, Inventario 32, caja 7, leg. $2, n^{\circ} 6$ y otras piezas más). Muchos otros títulos asociados a esta Casa también estuvieron concursados.

${ }^{49}$ Por sólo poner un ejemplo, cuando en 1606 se dictó sentencia de graduación en el concurso de la Casa de Osuna se contemplaron créditos de 350 acreedores repartidos por toda España, constando juros y censos, al menos, desde 1516 (Archivo del Marqués de Lozoya, Fresneda, $\mathrm{n}^{\circ}$ 25).

${ }^{50}$ Sociedad y Estado en el siglo XVIII español, Barcelona, 1976, pp. 346-350. También Ignacio Atienza, «La quiebra de la nobleza castellana en el siglo XVII. Autoridad real poder señorial: el secuestro de los bienes de la Casa de Osuna», Hispania, CLVI, 1984, pp. 49-81; más desarrollado en su tesis doctoral (Aristocracia, poder y riqueza en la España moderna. La Casa de Osuna. Siglos XV-XIX, Madrid, 1987). ${ }^{51}$ Véanse, a modo de ejemplo, los concursos el conde de Aguilar de Inestrillas, de 1592, a través de una oposición de Ruy Díaz de Fuenmayor, regidor de Calahorra, y consortes (Archivo de la Real Chancillería
} 
Por lo que se refiere a los concejos castellanos, también eran susceptibles de caer en la insolvencia, sin embargo, no por ello se creó un procedimiento especial para ellos; sólo he localizado unos pocos casos, relativo uno de ellos a la villa de Barajas de Melo, en el alfoz de Huete, aunque es muy probable que esto acabara sucediendo a muchos otros municipios, que se vieron así privados de sus bienes propios y comunales. Estos procesos sólo tenían una peculiaridad respecto a los ordinarios ${ }^{52}$ y era que para la enajenación de sus bienes los concejos necesitaban de la licencia regia con carácter previo..$^{53}$

El concurso de Barajas se había iniciado en 1651 y se prolongaría hasta 1674; aunque estaban en quiebra desde 1644, no fue hasta aquella fecha cuando acudieron ante el Consejo de Castilla para hacer cesión de sus propios, pues no podían hacer frente al pago de sus acreedores, debido a la esterilidad de los tiempos, malas y cortas cosechas, exceso de cargas y contribuciones y pérdida de vecinos y recursos econó-

de Valladolid, Fernando Alonso (F), 725/5) o del conde de Alba de Liste (testamentaría) entre 16111631, que contaba con 33 acreedores (ARChV, Pérez Alonso (F), 3.110/1-3.113/1). O los de los condes de Bailén en 1584-1608 (Archivo de la Real Chancillería de Granada, 87/2; también en Archivo Histórico Municipal de Úbeda, Fondo Judicial, 29/22 y 107/5) y de Villardompardo (porcón de la oposición instada por su hermana, marquesa viuda de Villamayor, en 1652) (BRAH, Porcones, 14/11.485, $\mathrm{n}^{\circ} 13$ ).

No siempre se conservan estos procesos completos, por ser, como digo, muy voluminosos, así, el concurso de Cristóbal de Porres Enríquez, conde de Castronuevo (Zamora), que se alargó de 1613 a 1643, va incluido en 109 piezas (ARChV, Pérez Alonso (F), 3.034/1-3.042/1). Se podrían añadir muchos más concursos nobiliarios.

También la oligarquía urbana podía ser concursada, como le ocurrió a don Diego Fernández de Córdoba, alférez mayor de la ciudad de Córdoba, a su muerte, en 1572 (ARChG, 714/11) o a don Fernando Coello de Portugal, veinticuatro de Jaén, señor de Pozoancho del Rey, alguacil mayor del Santo Oficio en Jaén y caballero de la Orden de Santiago (1692-1697) (AHPJaén, Justicia, 4.503).

Algo similar se puede decir de la aristocracia procedente del comercio (Luis Díaz de la Guardia, «La Corona y la venta de Gabia la Grande: el concurso de acreedores de Rodrigo de Tapia y Vargas, 1629-1700...», Actas del Congreso sobre la Andalucía de finales del siglo XVII, Cabra, 1999, pp. 6173).

${ }^{52}$ En 1554-1555 el corregidor de Salamanca realizaba información sobre la licencia pedida por el lugar de Villoruela para enajenar parte de sus propios para atender deudas contraídas en los pleitos que había mantenido con el conde de Monterrey y la villa de Villoria (AGS, Consejo Real, 157/6).

${ }^{53}$ El concejo de Rublacedo de Arriba, en la Bureba burgalesa, fue concursado (1748-1754) debido a la injuria de los tiempos, las malas cosechas y las reales contribuciones; por ello hizo cesión de bienes, solicitando al tiempo se despachase real provisión para ello; entre los acreedores se encontraban la Colegiata de Covarrubias y el duque de Frías, así como otros particulares. Se dictaron sentencias de graduación en 1751 y 1752, siendo ésta última apelada y confirmada en definitiva (ARChV, Pérez Alonso (F), 2.698/03).

El concejo de la capital toledana estuvo concursado entre 1606-1615, merced al voluminoso número de censos a que tenía que hacer frente (Archivo Municipal de Toledo, Censos. Concurso de acreedores, 1600). También el municipio de Arenzana de Arriba (La Rioja) estuvo concursado entre 1694 y 1699 (AHPLogroño, Protocolo 1.618/1, 326 folios), casi al mismo tiempo que el de Tórtoles (Guadalajara), en 1697-1699 (Archivo Histórico Provincial de Guadalajara, Protocolo 4.129/9). Poco antes le estuvo también el municipio de Logroño, en 1659 (ACDA, Alburquerque, Mayorazgo de Vergara, Inventario $292,4 / 7)$. 
micos; sus acreedores eran mayoritariamente instituciones eclesiásticas por sus censos. Se dieron sentencias de vista y revista, graduándose en ésta en primer lugar el concejo, al que se atribuyeron 100 ducados anuales, en concepto de alimentos. ${ }^{54}$

En ocasiones, los concejos supieron aprovechar la oportunidad que les ofrecía el concurso de sus señores para ganar su libertad; así ocurrió a fines de 1670, cuando la villa de Algete (Madrid) obtuvo la jurisdicción, señorío y vasallaje, además de las escribanías públicas del pueblo, por venta judicial que se les otorgó a raíz del concurso de los bienes de los marqueses de Cañete. ${ }^{55}$

\subsubsection{Pleitos de tercería}

En contadas ocasiones se localizan, así mismo, procesos llamados de tercería, que no deben confundirse con expedientes de otro tipo de tercería (de dominio, posesión, etc.). ${ }^{56} \mathrm{Se}$ trataba de causas en las que participan escaso número de acreedores - apenas un puñado de ellos- y no merecía la pena abrir concurso universal, de modo que se sustanciaban de forma mucho más rápida de lo habitual y resultaban menos onerosos. ${ }^{57}$

Uno de estos casos tuvo lugar en Villapresente (Valle de Reocín, Cantabria) en los años 1793-1801: se trataba del concurso de los bienes dejados por el difunto Antonio Sánchez de la Sierra, marido de María Ruiz de la Guarda, vecinos de aquel lugar. Antonio había acordado con Manuela García, viuda de José González de Bustamante, vecina del Puente de San Miguel, que ésta suministraría a su mujer e hijos alimentos de su tienda en tanto él se hallaba en Andalucía comerciando; abonaría el gasto hecho por su familia a un hijo de la tendera, que también se hallaba en tierras andaluzas. Al morir el concursado no pudo hacer frente a sus obligaciones, de modo que el curador de sus hijos anduvo pleiteando con evasivas para evitar el pago de la deuda. Al final concurrieron nuevos acreedores, formándose concurso atípico, por cuanto sólo era instado por Manuela. En realidad, no se llegó a abrir concurso para

\footnotetext{
${ }^{54}$ AHPCuenca, Sección Judicial, 104/1 (traslado de la ejecutoria del proceso original).

${ }^{55}$ ACDA, Inventario 451, 1.121 folios. La villa de Algete sería, a su vez, concursada en 1734, entrando en el señorío del conde de las Torres, como subrogado del duque de Vergara (Idem, Algete, Inventario 85, 4/2). El ducado de Algete sería concursado en 1805 (Idem, Inventario 458/2).

${ }^{56}$ En 1735 Francisca Antonia de Albóniga y Uriondo, mujer de Juan de Herrero, planteaba expediente de tercería en defensa de sus bienes dotales en la ejecución hecha en su marido por Manuel de Bildósola, comerciante bilbaíno, sobre rendición de cuentas por la fabricación de un molino de viento en Archanda, anteiglesia de Sondica (expediente acumulado al concurso de Bildósola, de 1732-1735, quiebra de tipo antiguo) (AHFVizcaya, Sección Judicial, Corregimiento, 3/2). Entiendo que se trata de una tercería de mejor derecho.

${ }^{57}$ Un proceso de tercería tuvo lugar en San Martín de la Vega (Madrid) entre 1710-1713 contra los bienes del difunto Juan Mudarra comerciante, a quien reclamaban pago de sus créditos dos colegas y el concejo de la villa (ARCMadrid, San Martín de la Vega, 13/262). Otro proceso de este tipo en Madrid en 1636-1648 (ARCMadrid, Familias Nobles, 5/313, $\mathrm{n}^{\circ} 1$ ).
} 
evitar gastos mayores a los menores de Antonio y María; además, había bienes suficientes para pagar a todos los acreedores, que se mostraron de acuerdo con esta forma de proceder. Naturalmente, así no se guardaba el derecho de otros posibles acreedores, puesto que no se habían fijado edictos convocándolos. El juez denomina este proceso como juicio ordinario de tercería. ${ }^{58}$

\subsection{Procesos y expedientes especiales: allanamiento, cesión de parte de pen- sión y consignación eclesiástica}

Se trata de distintas soluciones arbitradas para evitar las consecuencias de una cesión total de bienes en manos de los acreedores.

A partir del siglo XVII se documentan diferentes expedientes de allanamiento, como el que protagonizó en 1737 Juan de Enderica, vecino de la anteiglesia de Munguía, que cedió la mitad de su casería de Enderica para que, puesta en administración, se hiciese pago con sus rentas a sus acreedores, de acuerdo con sus grados, hasta ser totalmente satisfechos; con la condición de que no se le anduviese molestando con ejecuciones. Al tratarse de un expediente ordinario, el corregidor admitió el allanamiento y ordenó que se cumpliera así. ${ }^{59}$

Un privilegio parecido solían invocar los criados de la Casa Real para soslayar el pago inmediato de sus deudas; debe aclararse que como criados hay que considerar desde un modesto paje hasta miembros de la Real Academia de la Historia. ${ }^{60}$

Hablamos de los juicios de cesión de parte de sueldos para el pago a acreedores, de los que el Archivo de Palacio conserva buena cantidad de los siglos XVIII y XIX. Así, por ejemplo, entre 1826 y 1827, María Fernández de Rojas, viuda del pintor de cámara de S.M., Francisco Folch de Cardona (1744-1808), propuso acuerdo con sus acreedores a fin de que cobrasen sus créditos a prorrata, sin prelación, hasta ser totalmente pagados, cediendo para ello un tercio de la pensión que recibía regularmente de la Casa Real. La deudora quedó a disposición del Tribunal. ${ }^{61}$

\footnotetext{
${ }^{58}$ AHPCantabria, Valle de Reocín, 184/4, 220 folios.

${ }^{59}$ AHFVizcaya, Sección Judicial, Corregimiento, 326/12. Expuso en su petición que se hallana a que baian por sus grados cobrando cada uno su haver en las rentas que da y diere la mitad de la casa y casería de Henderica, con todos sus pertenezidos, perteneziente a mi parte, que produze de renta en cada un año diez y ocho ducados de vellón. Los acreedores deberían nombrar administrador para que la rija y govierne.

El allanamiento, finalmente, podía acabar en concurso, como le ocurrió a Bruno de Bidaurrizaga, vecino de la anteiglesia de Sopelana, que primero ofreció satisfacer a sus acreedores con las rentas de sus caserías de Urtiena y Uriarte, sitas en la anteiglesia citada y en la de Berango, respectivamente. Aprobado el allanamiento, comparecieron nuevos opositores, por lo que hubo de hacer cesión de bienes (1744-1748) (Idem, 3.201/5).

${ }^{60}$ Así, por ejemplo, en 1748-1772 se producía la testamentaría y concurso de Juan José Ortiz de Anaya, abogado de los Reales Consejos y académico de la Historia (Archivo General de Palacio, Sección Jurídica, 136/12; está perdida otra pieza de este concurso, 20/1).

${ }^{61}$ AGP, Sección Jurídica, 137/4; el expediente personal del pintor, en 1807, en Sección Personal, $2.625 / 27$.
} 
Los religiosos seculares gozaban, por otro lado, del beneficio del llamado «capítulo Odoardus», de solutionibus, recogido en las Decretales de Gregorio IX (3.23.3), mediante el cual podían hacer consignación o cesión de bienes a favor de sus acreedores, sin que pudieran ser encarcelados por ello. ${ }^{62}$ En el archivo diocesano de Cuenca he localizado un puñado de estos procesos, centrados en los años 40 del siglo XVII. Uno de ellos, por ejemplo, es instado en 1645 por el Lcdo. Juan Velázquez de Moya, presbítero, capellán de la ermita de San Antonio de Padua, extramuros de Cuenca, que presentó ante el juez eclesiástico la petición de consignación, junto con memoriales de bienes y deudas; el provisor del obispado finalmente rechazó la pretensión del presbítero: su merced dixo no a lugar la consignación que hace el dicho Lcdo. Juan Velázquez y los acrehedores sigan sus derechos como les conbenga ... ${ }^{63}$ Más éxito tuvo al año siguiente el Lcdo. Miguel López de Alarcón, clérigo y notario del Santo Oficio en Santa María del Campo, que pudo ir liberando alguna de sus deudas, aunque a punto de cerrarse el pleito, aparecieron nuevos acreedores. ${ }^{64}$

Lo cierto es que la impresión que dan estas demandas de consignación es de ser fraudulentas, presentándose acreedores fingidos para evitar la ejecución. ${ }^{65}$

Otro tipo de privilegio, detectado a través de las consultas del Consejo de Castilla, fue el concedido por Felipe IV por real cédula de 18/08/1654 a sus asentistas para pagar a sus acreedores con juros recibidos de la Corona; en 1656 fueron Francisco Fernández Solís y Felipe Denis Pacheco, factores y asentistas reales, los que se quejaron de que aquéllos no aceptaban ser pagados en papel, sino en metálico, queja que el año anterior ya se había producido con carácter general. ${ }^{66}$

\subsection{Las quiebras anteriores a 1737: tipos de procesos}

Debe reconocerse que el panorama que presentan las quiebras es ciertamente más complejo que el ya descrito de los concursos de acreedores; en primer lugar, ha de tenerse presente que cuando en el siglo XVI hablaban de la quiebra de tal persona física o jurídica no estaban pensando en un procedimiento concursal, sino en la situa-

\footnotetext{
${ }^{62}$ José Febrero, Librería de escribanos e instrucción jurídica ..., Madrid, 1783³, II, pp. 90-92

${ }^{63}$ Archivo Diocesano de Cuenca, Curia Episcopal, Audiencia, 954-D/17.

${ }^{64}$ ADCuenca, Curia Episcopal, Audiencia, 960/10.

${ }^{65}$ En 1613, sintiéndose acosado por varias deudas, el Lcdo. Juan Bautista Moreno, presbítero, vecino de Sevilla, acabó acogiéndose al Capítulo Odoardus, pidiendo se le asignasen alimentos, que se citase a todos sus acreedores y que se acumulasen todas las ejecuciones que estaban teniendo lugar (Archivo del Arzobispado de Sevilla, Justicia, 79, $3^{\circ}$ ).

En torno a 1722 don Francisco Lucas Guill, chantre de la catedral de Cartagena, como beneficiario del mayorazgo creado por su madre, doña Luisa Guill, renunciaba el Capítulo Odoardus y se obligaba a pagar los corridos de los censos que tenían cargados las tierras que había adquirido por venta judicial proveniente del concurso de don Agustín Martínez de la Rubia, todos vecinos de Murcia (Archivo Histórico Provincial de Murcia, Protocolo 3.569, fol. 94v).

${ }^{66}$ Archivo Histórico Nacional, Consejos, 7.165, $\mathrm{n}^{\text {os }} 16$ y 117, respectivamente.
} 
ción de bancarrota del sujeto; es por ello por lo que en muchas ocasiones el término «quiebra» aparece continuado con las palabras «y pleito de acreedores», indicando con ello que a la situación de insolvencia económica debía de seguir el procedimiento de amparo a sus acreedores.

Sea como fuere, no son muchas las quiebras modernas que habían sido editadas hasta los años 60 del siglo pasado; apenas he localizado dos: una del banco burgalés Aragón-Aguilar, en 1557-1564, estudiada por Manuel Basas, y otra del banquero limeño Juan de la Cueva (entre 1635 y fines del siglo XIX), glosada por María E. Rodríguez. ${ }^{67}$ En el primero de los casos la quiebra vino como consecuencia del alzamiento de los banqueros, que resultan encarcelados, siendo confiscados sus bienes y documentación profesional. Reunidos los acreedores, eligieron jueces árbitros, que dictaron sentencia, luego aprobada por el prior y cónsules del Consulado. Los fiadores de los quebrados y una minoría de los acreedores se opusieron al concierto celebrado entre el reo y el resto de los opositores. Finalmente, la Chancillería obligaría en 1564 a todos los disidentes a pasar por el convenio otorgado por la mayoría.

Por lo que se refiere a la quiebra habida en Lima, se inicia en 1635 cuando el banquero confesó al Virrey su situación de insolvencia; éste ordenó que se le buscase fiador. A la postre se abriría el proceso, tras lo cual se le encarceló y se intervinieron sus efectos y libros, oponiéndose un alto número de acreedores. Acto seguido, el Consulado dictó auto instando a todos ellos a nombrar un solo procurador. Se realizaron las dos operaciones, luego características, con la reintegración de la masa de la quiebra, realizada por el Consulado, por un lado, y, por otro, la exclusión de la masa, encomendada a los empleados del banco. A lo largo de la extensa administración de los bienes de la quiebra se vendieron algunos de éstos y otros se reservaron para que siguieran rindiendo al caudal. Con el efectivo obtenido se fueron abonando prorratas anuales a los acreedores, de acuerdo con las cuantías de sus créditos, si bien hasta finales del siglo XIX no se dieron por pagados todos ellos.

En ambos procesos vemos diseñadas las líneas maestras de lo que más tarde sería la clásica quiebra, ideas que desde pronto estuvieron presentes en los deseos de los Consulados, al menos, en el de Burgos; sabemos que en 1582, preocupado el Rey por la extensión de los alzamientos, consultó con la ciudad y los cónsules, que aconsejaron que

«para remediar los perjuicios que se seguían en las quiebras era preciso que la justicia del lugar donde se produjesen, tomase al mercader, inmediatamente, sus libros y papeles, hiciese inventario y metiese en la cárcel al quebrado. Luego se haría depósito judicial y la justicia nombraría a tres de los mayores acreedores para que examinasen las cuentas y viesen el modo de hacer un convenio, y si no, proceder al reparto de bienes, sueldo a libra, excepto la dote de la mujer y hacienda de menores si hubiere. Cada acreedor debía demostrar su deuda en el plazo de un año, pasado el cual, no podría reclamarla». ${ }^{68}$

\footnotetext{
${ }^{67}$ Véanse las referencias completas en la bibliografía de la nota siete.

${ }^{68}$ Manuel Basas, El Consulado de Burgos..., p. 102.
} 
Resulta natural que con todos estos escasos testimonios el profesor Alejandre en su mencionado trabajo tendiese a tomar este procedimiento como el habitual en la Edad Moderna, si bien en su exposición se fija en la quiebra en los territorios aragoneses para, luego, pasar a considerar el conocido procedimiento de quiebra, contenido en las Ordenanzas del Consulado bilbaíno de $1737 .{ }^{69}$ Sin embargo, como el mismo autor ya atisbó, el panorama que se nos presenta en los testimonios de archivo es mucho más complejo y nunca tan unívoco, de hecho, las quiebras que hoy llamaríamos mercantiles se solían sustanciar de acuerdo con un procedimiento muy cercano a los concursos ya mencionados.

Veamos varios ejemplos de esto:

A la altura de 1534 quebró en Madrid el cambio de la Corte ${ }^{70}$ Juan de Villarreal, natural del Valle de Gordejuela (Encartaciones de Vizcaya); como en tantas otras ocasiones, el inicio del procedimiento vino propiciado por la reclamación que hizo su viuda, Catalina de Bayona, que pidió el reintegro de su dote al juez — ante los alcaldes de Casa y Corte, comisionados sucesivamente, Lcdos. Juanes de Ávila, Pedro Girón y Francisco de Montalvo y el Dr. Ortiz-, que estaba valorada en 2.000 ducados; de inmediato, Diego de Bayona, administrador judicial, le hizo entrega de los mismos. El juez de estos «autos de liquidación», como se denomina el procedimiento por los incursos en él, dictó la intervención de los bienes del difunto y su puesta en administración, además de convocar a los posibles acreedores; durante los 10 años siguientes la justicia fue recibiendo las oposiciones que se fueron presentando paulatinamente por éstos, dictando sentencia caso por caso, en la que los daba por opuestos. No cobrarían el total de sus créditos, sino los $2 / 3$ de los mismos, pues así lo había dispuesto una cédula real. Progresivamente se fueron liquidando los bienes y haciéndose pago a prorrata, en plazos sucesivos, a los acreedores. ${ }^{71}$

Más drástica fue la solución a la insolvencia del ubetense Juan de Villalón, obligado de la carne de Baeza en 1544, que acabó huido en Indias, dejando a su familia en la miseria; todos sus bienes fueron ejecutados, no abriéndose el concurso sino muy tardíamente, una vez fallecidos el mercader y su mujer. ${ }^{72}$

${ }^{69}$ De hecho, el mencionado autor, a través del apéndice documental que incluye en su investigación, demuestra haber manejado 13 procesos en el Archivo de Indias: uno en la sección Justicia (1564, prisión por deudas), 8 en Escribanía de Cámara (1635, quiebra; 1641, espera; 1646, concurso por juez de comisión; 1654, quiebra; 1687, concurso; 1709, espera; 1710, quiebra, y 1753, quiebra), uno en Lima (1702, espera); otro en Indiferente General (1707-1715, quiebra), otro en Charcas (1737, quiebra) y otro en Audiencia de México (1779, quiebra).

${ }^{70}$ Estos cambiadores o banqueros solían dedicarse, especialmente, a recibir depósitos en metálico y hacer pagos contra ellos. Como dice Ramón Carande, «De los banqueros de la Corte se habla como personas que no cabe confundir con los cambiantes de las ferias, durante el curso de éstas. Manejan aquéllos más bien letras y libranzas» (Carlos Vy sus banqueros. I. La vida económica en Castilla (1516-1556), Barcelona, 1987, pp. 341-342).

${ }^{71}$ Archivo General de Simancas, Consejo Real, 170/3-23, 269/14 y 126/26.

72 Desgraciadamente, sólo se conservan dos piezas de este proceso (AHMÚbeda, Fondo Judicial, 1/31 y 92/34). He publicado el extracto de la probanza realizada por Juan de Vago, como tutor de los menores 
Por su parte, en Burgos, entre 1602 y 1609 tuvo lugar el concurso del vizcaíno Sebastián de Larrauri, regidor y depositario general de la ciudad cabeza de Castilla, que se sustanció como un concurso normal, si bien con un acuerdo de quita. ${ }^{73}$ El Consejo, mediante provisión, había ordenado que sólo entendiera en el caso el corregidor de la ciudad, avocando a las demás justicias y acumulando todas las ejecuciones en curso. Como digo, el procedimiento no difirió del pleito de acreedores habitual, dictándose finalmente sentencia de graduación, en julio de 1604, incluyendo entre los acreedores a la Hacienda real. Un año se demoraron los acreedores en llegar a un acuerdo de quita con el concursado,${ }^{74}$ ante la dificultad de administrar los bienes concursados y, sobre todo, de liquidarlos a precio adecuado. En junio de 1607 el Consejo aprobaría el acuerdo, con todos los pronunciamientos favorables para el concursado —se le declaró como hidalgo notorio, a pesar de lo cual siguió encarcelado hasta la mencionada aprobación-.75

En el ámbito sevillano también nos encontramos con procesos que traen causa de los pleitos de acreedores, pero con diversas peculiaridades. Así, entre 1608-1612 se produjo la quiebra, fuga y alzamiento de Pedro Rodríguez Zamudio, fiador del flamenco Arnao de Bautres, ambos mercaderes de oro y plata. Ante el presidente de la Casa de Contratación, que fue recibiendo las oposiciones que se fueron presentando, dictando al final sentencia de graduación. Sabido el alzamiento, fue dictado auto de prisión y embargados sus bienes; también se siguió la causa contra Arnao, apareciendo luego terceros opositores. La sentencia de primera instancia fue confirmada, dándose una tercera avivando el trance y remate de los bienes concursados. ${ }^{76}$

de Villalón y su difunta mujer, Luisa de Segura, sobre la situación de insolvencia de la familia, contenida en la primera de las piezas mencionadas (Las comunidades conversas de Úbeda y Baeza en el siglo XVI, Jaén, 2008, pp. 103-109).

${ }^{73}$ AHN Nobleza, Bornos, 831/1, 132 folios; venta judicial de diversas heredades en Rabé de las Calzadas (Burgos), antes propiedad de Larrauri, a favor, probablemente, del mayorazgo de los Moneda, integrado en la Casa de Bornos; no se incluye el proceso completo, pero sí lo más sustancial.

Un aspecto bien distinto presenta el concurso seguido en 1677-1711 contra don Francisco Vermolen, mayordomo del cabildo y mesa capitular de la Iglesia de Málaga, contra su viuda, doña Margarita Germana Lince de Brun, vecina de Málaga, y su sobrina y heredera, doña Luisa Lince de Palma, vecina de Madrid. Aquí destacan las disputas entre los acreedores por la administración de los bienes concursados y, por ende, por el nombramiento del administrador; no se recoge acuerdo de acreedores, dando la impresión de no haber habido graduación de créditos y de haberse adjudicado los bienes directamente a los opositores. El Consejo no interviene al no haber interés de la Hacienda regia en la causa (ARChGranada, 2.557/4, incompleto).

${ }^{74}$ Después de lo qual hubo acuerdo y concierto entre el dicho Sebastián de Larrauri y de los dichos acrehedores y fiadores, en que se les hubiese de pagar las cantidades de mrs. que por la dicha sentencia les estavan mandados pagar de los vienes de los dichos Sebastián de Larrauri, a raçón de sesenta y seys por ciento, y de los de sus fiadores de los depósitos, a raçón de ochenta por ciento, con lo qual se cumpliesse y executase lo contenido en la dicha sentencia (fol. 87r).

${ }^{75}$ Atento que por el dicho processo no consta ni se prueba al dicho Sebastián de Larrauri haver ocultado vienes algunos suyos ni de los depósitos en él fechos, ni haver hecho fuga de su persona al tienpo y quando hizo el dicho pleyto de acrehedores ... (fol. 31v-32r).

${ }^{76}$ Archivo General de Indias, Contratación, 74B, n 3, 391 folios. 
Entre 1567-1571 se siguieron autos de pago a acreedores por parte del jurado Francisco Bernal mercader, vecino de la collación sevillana de San Bartolomé; se iniciaron cuando el alguacil acudió a casa del jurado a cobrar los fletes de los navíos venidos de Nueva España, que habían traído a Bernal cochinilla y cueros; un criado le informó de que ambos esposos estaban retraídos, habiendo cesado en sus pagos. Los capitanes de esos navíos pidieron que los productos traídos se vendiesen para hacer frente al pago de los fletes, como se hizo. Luego fueron apareciendo nuevos acreedores, incluida la mujer, que reclamó su dote, y la parte del Rey, sin abrirse concurso universal. De este modo, los bienes del jurado fueron embargados, haciéndose pago de algunas de sus obligaciones. No obstante, el concursado llegó a un acuerdo con sus acreedores por separado, que acordaron levantarle el embargo. ${ }^{77}$

Por otro lado, en 1565-1566 se desarrolló un proceso a instancias del mercader Francisco de Toro, vecino de la collación de la Magdalena, que comenzó compareciendo ante el Asistente de la ciudad, pidiéndole que convocase a junta a sus acreedores, a fin de llegar a un acuerdo con ellos para pagarles sus créditos. Finalmente, los acreedores designaron entre ellos a tres jueces árbitros que determinaron la causa de acuerdo con el deseo de la mayoría, decidiendo vender la casa, oro y plata, además de las mercancías del insolvente; también acordaron se les diese poder en causa propia para desplazarse a las Indias a cobrar el resto de su hacienda. El producto de todo ello se repartió a prorrata entre los acreedores adheridos al acuerdo. Reconocieron también que la quiebra del mercader había sido fortuita. ${ }^{78}$

Pasado siglo y medio, parece haberse consolidado en el ámbito jurisdiccional del Consulado hispalense la práctica de la quiebra sustanciada como concurso ordinario; a comienzos del siglo XVIII había quebrado Gabriel Morales y Cía., comprador de oro y plata en Sevilla, haciendo cesión de bienes. El proceso conservado se refiere a los autos seguidos (1706-1710) por la marquesa viuda de Castromonte y los albaceas del marqués, don Luis Ignacio de Baeza, gentilhombre y chanciller del Consejo de Hacienda, contra el defensor de la quiebra y los diputados de los acreedores de las tres clases, por dos vales - procedentes de Cartagena de Indias y de Nueva Españaque los demandantes entendían que no pertenecían a la masa de la quiebra, pues les habían sido cedidos por un crédito que el marqués tenía contra la casa de Morales. Tanto el Consulado de Sevilla como el Consejo de Indias, en apelación, consideraron que el quebrado había tranmitido al cesionario la propiedad de los 85.000 pesos de plata contenidos en ambos documentos. ${ }^{79}$

\footnotetext{
${ }^{77}$ AGI, Contratación, 710, $\mathrm{n}^{\circ}$ 21, 142 folios.

${ }^{78} \mathrm{AGI}$, Contratación, $714, \mathrm{n}^{\circ} 2,5^{\circ}$. Inserto en concurso posterior, habido en 1575 , contra el mismo mercader y litigado entre Martín Cano, mercader de México, socio de Toro, como defensor de sus bienes, y Roberto de Acre, estante en Sevilla, como procurador de los acreedores; finaliza la parte conservada otorgándose año y medio de plazo al defensor para realizar sus probanzas en Indias.

${ }^{79}$ AHN, Consejos [Casa de Contratación de Cádiz], 20.197, $\mathrm{n}^{\circ} 1$. En la pieza siguiente se contiene la cesión hecha en 26/09/1702 a favor del marqués, haciendo constar que diferentes documentos librados
} 
Por lo que se refiere a Vizcaya, contamos con numerosísimos testimonios de concursos, que son enjuiciados por sus corregidores, de acuerdo con el procedimiento ejecutivo ya comentado. En ellos se vieron implicados abundantes mercaderes, aunque sólo se remitía el conocimiento de la causa al Consulado de Bilbao cuando eran vecinos y pertenecientes al mismo y sus opositores eran también mercaderes. Así ocurrió, por ejemplo, en 1671, en los autos seguidos por Alejandro Esteban y Juan Paulmier, mercaderes de Tours, contra Bartolomé Dos, de la misma nacionalidad y oficio, pero residente en Bilbao - en esos momentos ausente-, por el reintegro de unas mercancías. ${ }^{8}$ Más complicado debió de ser recorrer el camino inverso una vez que se hubo introducido el nuevo procedimiento en 1737. Este es el caso del proceso de Juan Antonio de la Piedra, dueño de un obrador de ferretería en Bilbao en 1825, iniciado por el protesto de un pagaré, al que luego se sumó su esposa, Petronila de Echebarría, por sus dotales. Comenzó como quiebra y terminó como concurso, ya que la Junta Suprema de Competencias dictaminó que la causa pertenecía, no al Consulado, sino a la justicia ordinaria de Bárcena de Cicero (Cantabria). ${ }^{81}$

Entre los muchos casos que se podrían aducir, en relación con concursos de acreedores, traigo a colación el seguido entre 1648 y 1666 contra los bienes de Domingo de Barandica mercader, dueño de la casería de Irusta (en la anteiglesia de Abando), y contra su viuda y socia, Isabel de Lorte Echébarri. Tras seguir las fases habituales en los concursos ordinarios, termina con la correspondiente sentencia de graduación y el remate de sus bienes, una vez acumuladas diversas vías ejecutivas.$^{82}$ Los créditos venían documentados en tres obligaciones, que la viuda alegó haber suscrito por fuerça, miedo, biolencia y themor; su queja no fue atendida, dictándose sentencia de graduación, luego confirmada. Estando en fase ejecutiva, Isabel apeló ante los Dipu-

a favor del quebrado eran, en realidad, de aquél, con quien mantenía cuenta corriente. Poco después (Sevilla, 24/04/1703) el quebrado se ratificó en la cesión hecha a Castromonte en las cantidades aún no abonadas, obligándose al saneamiento: de suerte que no sólo serán siertas y verdaramente devidas por los dichos deudores, sino que serán exigibles y cobrables, de suerte que, si por falenzia de los deudores o qualquiera dellos, por muerte de sus personas, faltas de sus caudales o créditos o por otra qualquiera rasón o acidente, que no sea por culpa o omisión culpable del dicho exmo. señor marqués, no se cobraren algunas o algunas de las partidas desta sesión, las a de repetir y cobrar su Excelencia en virtud deste saneamiento de mí y de la dicha mi Compañia (Idem, 20.197, n²).

${ }^{80} \mathrm{El}$ defensor de los bienes del quebrado expuso que por cuanto todos los que se an opuesto son mercaderes comerciantes que asisten en esta villa, con que conforme al derecho y leies reales toca el conocimiento de esta causa al fiel y cónsules de la Casa de Contratación, lo qual represento a v.m. para que, reconociendo ser así, se sirva remitir el conocimiento de la causa al Consulado, para que se ebiten nulidades. Así lo concedió el corregidor; el resto del proceso se continúa ante el Consulado, que sigue el procedimiento concursal habitual, si bien se entremezclan autos criminales contra Diego Moynier, factor de Juan de Barauq y Cía., mercader de Montauban, por fraude y ocultación de bienes. Alcanza más de 300 folios, sin que nos haya llegado la sentencia de graduación y la ejecución correspondiente (AHPV, Sección Judicial, Corregimiento, 95/8).

${ }^{81}$ AHFVizcaya, Sección Judicial, Corregimiento, 495/13.

${ }^{82}$ AHFVizcaya, Sección Judicial, Corregimiento, 172/23. 
tados Generales, alegando que su apelación tenía los dos efectos suspensivo y debolutorio, y por lo consiguiente no se puede tratar sobre el remate y benta de los bienes executados asta que se ejecutorie o pase en autoridad de cosa juzgada sobre la prelación de los acrehedores, como es llano en derecho y recivido en práctica en todos los tribunales. A pesar de la defensa numantina ofrecida por la viuda, se siguió con el remate y acabó perdiendo su casería.

El panorama observado en el Consulado de Bilbao resulta mucho más uniforme, comparado con lo descrito en otras partes de Castilla, a tenor de los procesos conservados; en este caso, se mantuvo siempre la denominación para éstos de quiebra (hecho económico) y concurso (proceso), incluso después de las novedades introducidas en 1737.

Pero es que, además, antes de esa fecha las quiebras se tramitan de un modo similar a los concursos; aunque no he visto muchos de estos procesos de quiebras consulares, creo que con dos ejemplos será suficiente para demostrar esa realidad. En 1657 Pedro de Aresti, en nombre de su difunto hijo Francisco, inició proceso ejecutivo contra Martín de Basualdo, comerciante de vinos, en virtud de una escritura de obligación; enseguida aparecieron otros opositores, por lo que hubo que dictarse acumulación (se junten y acomulen todos los dichos pleytos y anden juntos debaxo de una cuerda). A la altura de 1661 se pronunció la correspondiente sentencia de graduación. ${ }^{83}$

Para 1703 era José de Goitia, síndico tesorero del Consulado, quien inició ejecución contra María y Gracia de Echebarría, francesas, hijas de Juan de Echebarría y Catalina Martínez, vecinos de Viana y residentes en Bilbao, propietarias tras la muerte de éstos de una lonja donde comerciaban con aguardiente. Iniciada la tasación del caudal, se opuso a la ejecución el también francés Miguel de Faguaga, vecino de Ciburu (Ciboure). Se dictó auto de acumulación y de graduación, resultando que el segundo y último graduado quedó insatisfecho en su crédito. Pasado un año, el prior y cónsules dictaron nueva sentencia. Sin embargo, fueron apareciendo nuevos acreedores, de modo que hubo que dictar acumulación de ejecuciones, abrir concurso universal, nombrar defensor, etc. hasta desembocar en sentencia de graduación (1709). Salvo uno que apeló, todos los demás acreedores consintieron la sentencia, haciéndoseles pago hasta donde alcanzaron los bienes concursados y constituyendo las fianzas habituales. ${ }^{84}$

\subsection{La quiebra en el Consulado de Bilbao a partir de 1737}

La aprobación de las Ordenanzas del Consulado bilbaíno en 1737 supuso un cambio de paradigma, al menos, en lo relativo a las quiebras mercantiles, por cuanto se estableció un nuevo sistema mucho más rápido y ágil, que permitía la negociación

\footnotetext{
${ }^{83}$ AHFVizcaya, Sección Judicial, Corregimiento, 368/57.

${ }^{84}$ AHFVizcaya, Sección Judicial, Corregimiento, 407/9.
} 
del quebrado con sus acreedores, que se organizaban en junta, la cual aprobaba la quita y la espera precisas para levantar la quiebra. ${ }^{85} \mathrm{El}$ éxito de esta nueva regulación hizo que se extendiera por todos los demás Consulados hispánicos. ${ }^{86}$

De acuerdo con el propio título 17, se establecían tres clases de quiebras: de primera clase (fortuita o inocente, insolvencia temporal), de segunda (inculpable) y de tercera (dolosa, que llevaba la consideración de robo, con infamia). La calificación de la quiebra se realizaba al final del procedimiento. Este se iniciaba bien con la presentación de inventario de activo y pasivo por parte del quebrado o por denuncia de sus acreedores. Diligencias preliminares eran el aseguramiento de la persona, bienes y documentos del fallido, la recogida de llaves, el inventario de libros y papeles del comercio, el inventario de bienes y la intervención de su correspondencia en Estafeta.

Acto seguido, se producía el depósito y administración de los bienes, nombrándose un depositario interino hasta la celebración de la Junta. De esa junta salían los síndicos-comisarios, cuyas funciones eran examinar la situación de créditos y acreedores,

${ }^{85}$ Ordenanzas de la Ilustre Universidad y Casa de Contratación de la M.N. y M.L. villa de Bilbao (insertos sus reales privilegios), aprobadas y confirmadas por el rey, nuestro señor, don Phelipe Quinto (que Dios guarde), Madrid, 1737, capítulo 17: «De los atrasados, fallidos, quebrados o alzados, sus clases y modos de procederse en sus Quiebras».

${ }^{86}$ Entre 1769 y 1771 el marqués de Negreiro, vecino de Lima, litigaba con los interventores de los acreedores de la Casa en quiebra de Vicente Raimundo de Eguía Olarte y Guisasola, de Cádiz, por el abono de 4.000 pesos. En 1756 se habían celebrado sendas juntas de acreedores, en las que actuaron como síndicos los interventores, que esperaban cobrar el grueso de la masa de la quiebra en Buenos Aires. Finalmente, se prorratearon los bienes existentes el $80 \%$ a los acreedores escriturarios y el 14 a los tenedores de vales. Negreiro apeló ante el presidente del Consulado, obteniendo sentencia que le adjudicaba el $60 \%$ hasta completar el total de su deuda. El último documento conservado en este expediente es la apelación de los interventores contra dicho fallo (AHN, Consejos [Consulado de Cádiz], 20.210, $\mathrm{n}^{\circ} 3,3$ piezas de 180 folios). Como se puede apreciar, en Cádiz en esas fechas se seguía el nuevo modelo de quiebra.

En cambio, en el proceso seguido (1766-1773) por Guillermo Casañas, vecino de Santa Cruz de Tenerife y otros vecinos de la misma ciudad, La Orotava y La Laguna contra Antonio González de Mesa, capitán y maestre de la fragata Nuestra Señora de La Soledad y San Antonio, más conocida como «La Conquista» — nave apresada por los ingleses en San Cristóbal de La Habana en diciembre de 1762 y recobrada en 1764-, por sus créditos, se siguió el concurso de acreedores clásico, habiéndose visto la causa ante el juez superintendente del comercio con Indias en Canarias y subdelegado de la intendencia general de marina de Cádiz en las Islas. Casañas apeló ante el Consejo de Indias, que confirmó la sentencia de graduación de aquél con ligeros retoques.

González de Mesa había sido hecho prisionero por los británicos en La Habana, perdiendo todos sus bienes; la fragata le fue confiscada, recomprándola más tarde a sus captores, para usarla en la evacuación de la guarnición y familias españolas de Pensacola. Hizo consignación de la nave a favor de sus acreedores (AHN, Consejos [Consulado de Canarias], 20.281, $\mathrm{n}^{\circ}$ 2, 4 piezas de 429 folios).

Menos sorprende es que se use el mismo procedimiento en el proceso seguido (1761-1770) por el conde de Torre Velarde, vecino y comerciante de Lima, contra el marqués de Mena Hermosa, residente en Madrid; aquél había prestado a éste 3.506 mulas para abastecer a los indios de la provincia de Tarma en 1763, de la que el marqués fue gobernador. En primera instancia entendió la auditoría de la capitanía general de Lima, llegando en apelación ante el Consejo de Indias, que confirmó la sentencia de graduación emitida en Perú (AHN, Consejos [Audiencia de Lima], 20.290, n² 2). 
realizar las diligencias precisas para el cobro de las deudas, informar de la insolvencia al resto de acreedores y convoca Junta general.

Esta Junta general era el órgano deliberante: la primera de ellas la convocaba el Consulado, la segunda, los síndicos-comisarios; éstos informaban al resto del estado del quebrado y de los créditos contra él y proponían la concesión de salvoconductos al quebrado para comparecer ante la Junta, decidiendo la Junta sobre el ajuste propuesto por aquél. Los acuerdos debían de tomarse por unanimidad o por mayoría, bien concurriendo el $75 \%$ de los acreedores y $2 / 3$ de los créditos representados, bien $2 / 3$ de los acreedores y el $75 \%$ de los créditos representados. Además, hacían la propuesta de calificación de la quiebra a prior y cónsules. Los acuerdos tomados en junta debían ser ejecutados por el Consulado.

Punto capital era la fijación de la masa de la quiebra, para lo que, primero, había que excluir aquellos bienes no pertenecientes al quebrado (la dote de la mujer del quebrado, los efectos depositados en sus manos, los tenidos como comisionista, etc.) $\mathrm{y}$, segundo, reintegrar los bienes enajenados en fraude de la quiebra, limitándose el período de retroacción a un corto espacio de tiempo, no determinado; esta operación iba dirigida contra el quebrado y sus encubridores o acreedores fingidos.

Lo habitual era que Junta y quebrado celebraran un acuerdo de quita y espera, a falta del cual se dictaba sentencia de graduación, haciéndose pago líquido o con bienes adjudicados a tasación: los acreedores privilegiados e hipotecarios por sus grados y los personales sueldo a libra. Terminaba el procedimiento con la rehabilitación del quebrado.

Como parece lógico suponer, este novedoso procedimiento de quiebra empezaría a aplicarse a partir de la confirmación de las mencionadas ordenanzas consulares, sin embargo, en la práctica de su tribunal se aprecia que en los años anteriores a 1737 ya se fueron introduciendo elementos nuevos en la sustanciación de las quiebras, que podríamos denominar como quiebras de transición: en 1718 se produjo la quiebra y concurso del comerciante irlandés Patricio Kelly, residente en los Arenales bilbaínos, retraído en el monasterio de San Mamés de Abando; se intervinieron sus efectos y se hizo inventario de sus bienes por parte del prior y cónsules; a continuación se presentaron ejecuciones por parte del administrador de la renta de lanas, por Bartolomé Muilman, mercader de Amsterdam, librador de una letra de cambio, por Sebastián de Medrano, vecino de Madrid, que había remitido a Santa Cruz de la Palma (Canarias) bienes que estaban en la lonja de Kelly, etc. El auto final ordenó vender los bienes de la masa en público remate, precedida tasación con citación de los acreedores, y que los deudores de Kelly, incluida Francisca de Quintanilla, abonasen al caudal lo debido. ${ }^{87}$

Entre 1728 y 1731, además, se fulminó otro proceso de transición en las personas de Gabriel de Olarte, retraído en el monasterio de San Agustín, extramuros, y Mag-

\footnotetext{
${ }^{87}$ Faltan los dos primeros folios, así como el desenlace final del procedimiento (AHFVizcaya, Sección Judicial, Corregimiento, 2.197/2).
} 
dalena de Aguirre, su mujer, vecinos de Bilbao. Olarte comenzó haciendo cesión de bienes, siguiendo diversas oposiciones, entre ellas, las de su esposa por su dote. Termina el procedimiento con un acuerdo de quita y espera, en que el matrimonio se obligaba a pagar el $25 \%$ de los créditos documentados y los acreedores pedían la liberación del quebrado, como así se hizo. ${ }^{88}$

Así mismo, en 1735 se celebraron dos quiebras que, de acuerdo con el nuevo paradigma, se calificarían de segunda clase: las de los hombres de negocios bilbaínos Juan de Larralde ${ }^{89}$ y Marcos de Aranguren. ${ }^{90} \mathrm{Y}$ es que la mayor parte de las quiebras que tuvieron lugar a partir de la entrada en vigor de este nuevo procedimiento eran, como cabía esperar, de primera o segunda clase.

Por ejemplo, en 1751 tuvo lugar una que acabaría siendo calificada como fortuita; José Jacinto de Bringas, comerciante bilbaíno, se había refugiado en el convento de San Agustín, extramuros de la villa, no sin antes haber entregado la llave de su domicilio en manos de uno de los cónsules. Tras realizar los trámites habituales, se encontraron 19 acreedores, que se reunieron en junta para designar síndicos. Luego aparecieron otros opositores, como el hombre de negocios de Amsterdam, Luis Michel. Reunido con todos sus acreedores, Bringas celebró acuerdo con la mayoría de ellos, tanto en personas como en deudas, por el que les cedía en pago un crédito de 65.075 reales de vellón que tenía contra don Pedro Martín de Armendáriz, vecino de Burgos. No todos estuvieron de acuerdo en lo convenido, si bien el informe elaborado por el síndico recomendaba aceptar la oferta del quebrado. A la vista de dicho informe los acreedores decidieron pasar por aquella cesión, con lo que se cerró el procedimiento. ${ }^{91}$

Sin embargo, las quiebras más abundantes serían las de segunda clase («culpados levemente»). Una de ellas sería la que se ventiló entre 1765 y 1767, instada por Carlos de Uribe, contramaestre de navíos, vecino de Deusto, en nombre de los carpinteros y calafates que habían construido el «Santa Catalina», contra Antonio Real de Asúa, maestro constructor de navíos, vecino de Abando-se hallaba refugiado en los astilleros de Guarnizo, trabajando a jornal一, por los jornales de los 30 días que habían

\footnotetext{
${ }^{88}$ AHFVizcaya, Sección Judicial, Corregimiento, 2.066/10, 157 folios (en mal estado).

${ }^{89}$ Iniciado por Antonio de Albóniga, factor de Salvador de San Martín, comerciante de San Juan de Luz, que le había remitido varias cargas de bacalao en tres navíos; luego se suman varios comerciantes de Londres, de apellidos vascos; celebrada junta, los acreedores comunican al Consulado que han acordado con el quebrado el pago de $\operatorname{los} 2 / 3$ de sus créditos y la espera de dos años; se le acaba reponiendo en su buen crédito. Había durado el procedimiento un mes y 11 días (AHFVizcaya, Sección Judicial, Corregimiento, 255/21).

${ }^{90}$ El quebrado se había retraído en el convento de los jesuitas por no poder pagar algunas letras aceptadas; se le intervienen papeles y bienes (bacalao, azúcar y sebo); se celebra junta, que nombra contadores, depositarios y síndicos; se producen distintas operaciones de fijación de la masa; aparecen nuevos opositores y se presenta ajuste celebrado por el quebrado en 1726, pero no se incluye la resolución final (AHFVizcaya, Sección Judicial, Corregimiento, 267/58). Curiosamente, cuando en este proceso se mencionan las Ordenanzas, se añade que habían sido recientemente aprobadas por el Rey.

${ }^{91}$ Había durado el proceso seis meses y 9 días (AHFVizcaya, Sección Judicial, Corregimiento, 337/34).
} 
empleado en la obra de la nave. Luego, el capitán de la nave, José Daugerote, que deseaba partir para Bristol, pidió el desembargo de la misma, mientras que Clara de Bengoechea Alberdi, mujer del quebrado, pedía sus dotales. Se presentaron otros opositores y se acumularon otras ejecuciones. Se levanta el embargo de la nave, por haber sido ya botada en Santurce, constituyendo las correspondientes fianzas. En junta se nombran síndicos, que confirman la conformidad de sus cuentas.

Se declara la quiebra de segunda clase, pues, aunque Asúa no llevaba sus libros con la claridad que los comerciantes, por sólo saber del arte y oficio de carpintería $y$ ser notorio y constante la desgracia e injuria de los tiempos y que la carestía de alimentos y materiales han ocasionado atrasos y deudas. Se le alza la prisión. A continuación los síndicos pidieron la convocatoria de junta, en la que se acepta la oferta de Asúa de pagar el 19\% de la deuda, en dos plazos de 9 meses. Al no estar de acuerdo con ello la mayoría de los trabajadores, se celebró nueva junta, en la que finalmente se aceptó lo ofrecido por el quebrado: pagaría de inmediato el 12\% de la deuda, obligándose a abonar junto a su mujer — que renunciaba a percibir su dote- un $4 \%$ más en el plazo de un año. La mayoría pasó por esto, imponiendo como condición que, si mejorase su situación económica, les satisficieran la totalidad de la deuda. En el auto final se ordena poner en depósito la parte correspondiente a los disidentes y devolver lo restante al quebrado. A pesar de esto, los acreedores no acordes siguen presentando otras peticiones, sin que el Consulado provea cosa alguna. ${ }^{92}$

En 1779 tuvo lugar otra quiebra de segunda clase, en la persona de Carlos González de Echábarri, comerciante de Bilbao. Los cónsules, sabido que éste había dado punto a sus negocios, ordenan intervenir su persona y bienes, por inventario; realizado el resto de las diligencias previstas, se llama a junta, si bien los acreedores se muestran remisos a asistir y los síndicos nombrados se resisten a aceptar su designación. En nueva junta se sortean entre todos, asistentes o no, los dos cargos de síndicos. Estos tasan sus bienes en 10.000 reales y se quejan del mal estado de la contabilidad del quebrado, el cual ni su mujer sabían escribir; había muchos acreedores de fuera de la villa y por pequeñas cantidades. Además, renunciaron a sus cargos y a los haberes que pudieran haberles correspondido.

Se convoca nueva junta y no concurre nadie. A la postre designan a un solo síndico, que presenta un estudio de la situación financiera de Echábarri (estado de las dependencias), en el que concluye no haber encontrado dolo o fraude en el quebrado, sus beneficios superaban los 3.000 reales y sus bienes casi alcanzaban los 6.000 reales, teniendo unas deudas acumuladas de 32.000 reales. Prior y cónsules declararon la quiebra como de segunda clase, alzando la prisión del quebrado y permitiendo a los acreedores perseguir sus créditos como les conviniera; a Echábarri se le previene de que, en caso de que quisiera seguir en el comercio, librase y aceptase letras por medio de apoderado, so pena de proceder contra él. El síndico pidió nueva junta a

\footnotetext{
${ }^{92}$ AHFVizcaya, Sección Judicial, Corregimiento, 454/16, 173 folios.
} 
fin de ver lo actuado y decidir el modo de cobrar. No habiendo concurrido síndico ni quebrado, se ha de fijar nueva fecha para la reunión. En ésta supieron que un acreedor había perdonado su deuda y el síndico previno al resto de que podrían cobrar cada uno el $18,5 \%$ de sus créditos, menos gastos judiciales; para evitar éstos, Echábarri propuso abonarles el $20 \%$ durante 24 meses en 3 plazos, si bien lo que aceptaron fue cobrar el $22 \%$ en 21 meses en 3 plazos..$^{93}$

Por último, entre las escasas quiebras dolosas conservadas (de $3^{\text {a }}$ clase), destaca la que se siguió entre 1755 y 1771 contra el comerciante inglés Carlos Walcott, activo en Bilbao. El 26 de abril de aquel año el prior y cónsules supieron que éste había puesto punto a sus negocios y se había retraído en el convento de San Agustín. Tras entregar a Pedro Beekvelt e hijo, comerciantes, una partida de grasa de ballena de su propiedad, que estaba en la lonja del quebrado, se realizaron las diligencias de rigor y se convocó junta de accionistas. En la misma se nombran síndicos y traductor jurado (Juan Enrique Goosens). Se presentan algunos opositores al concurso y autos de quiebra en curso, entre ellos, Guillermo Burgo, mancebo de escritorio, que se opone por el bacalao y enseres de hogar depositados en casa de Walcott por una tía suya. Los síndicos, tras tachar este proceso de «quiebra fraudulenta», se niegan a tal pretensión, además, el mancebo es reo higualmente que su amo en los fraudes, dolos y maldades que an hecho y cometido, apoderándose de muchos y cuantiosos caudales agenos, en que, unidos y confederados, an proseguido y continuado en muchos años, qual patentemente se descubre por sus desvaratados libros.

Del mismo modo los síndicos rechazaron la pretensión de Juan Bautista de Hormaza de ser acreedor por una letra de cambio: que sólo había documentado los 3.020 reales de la letra, pero no el resto de las deudas que reclamaba de las demás letras que habona a Walcot, y se le fueron efectibamente pagadas, y de esta forma bien lejos de ser Hormaza acrehedor de cantidad alguna, y mucho menos de la que pretende a los vienes de la dicha quiebra, es lexítimo deudor a ellos y, consiguientemente, a la masa común de acrehedores de considerables reales.

También rehusaron abonar otras cantidades a distintos opositores vizcaínos y extranjeros, si bien el Consulado estimó que las deudas laborales documentadas se pagasen bajo fianza. Habidos otros incidentes de pago con otros opositores, los síndicos pidieron que los paquebotes Santa Clara y San Nicolás y la goleta San Antonio, atracadas en Cádiz, con sus cargas, que estaban siendo allá rematadas a petición de los Butler y Cía., se sumasen a la masa de la quiebra, pues a aquella compañía ni remotamente les toca.

A fin de acelerar los trámites de la quiebra, los acreedores consintieron que Walcott volviera a la villa y durante un año anduviera allí para estar a cuenta con ellos. Este salvoconducto se le había dado a instancias de Juan Ángel de Zuazo, notario del Santo Oficio y vecino de Portugalete, además de acreedor del quebrado. En junta se comunicó a los inasistentes que firmasen el documento, pues la mayoría ya lo había hecho.

\footnotetext{
${ }^{93}$ AHFVizcaya, Sección Judicial, Corregimiento, 309/18, 44 folios.
} 
Juana Joyce, mujer del quebrado, pidió traslado del mismo, a fin de terminar el proceso y en beneficio de mis tiernos hixos.

Contestaron los síndicos que la quiebra era fraudulenta y dolosa, que Walcott había arruinado a muchos mercaderes y a sus familias con sus engaños, estafas y maldades intolerables, alzándose y dejando sus libros en un estado desastroso; que Walcott, su mujer y su factor merecían sufrir la pena capital, como lo tenían pedido en la causa criminal que tenían abierta contra ellos en ese mismo tribunal. Por eso Juana no podía ser oída; los cónsules rechazan la petición de ésta y deciden que no se la admita más escripto en el asumpto, por no ser parte para ello. Ante la insistencia de la mujer - que ya había cobrado su dote-, se celebra junta de acreedores, en la que uno de los síndicos afirma que Juana no era parte y que su intención era librar a su marido de la causa criminal que se le seguía por ser la quiebra de tercera clase; que debía estar en la cárcel. Los demás acreedores callaron; sólo tres de ellos dijeron que, a la vista del mal estado de los libros, se librase el salvoconducto por 10 o 12 meses para terminar los autos. Tras denegar la pretensión de la mujer, aceptan librar la licencia, reservándose su derecho a continuar los autos criminales. Así se aprueba por auto.

Finalmente, Walcott falleció, por lo que los cónsules encargaron a los síndicos y otros acreedores que liquidasen los bienes del reo y que hasta donde alcanzaren se pagasen sus créditos documentados. ${ }^{94}$

Un ejemplo de autos criminales contra mercader alzado se encuentra entre los procesos del Consulado de Cádiz: en 1789-1790 se desarrolla el procedimiento seguido por Sebastián Batlle, vecino y comerciante de Cádiz, en aquellos momentos ausente en Barcelona, contra Francisco Buch, de la misma vecindad y oficio, que estaba preso en la cárcel pública por alzamiento de bienes y a disposición del tribunal. Batlle pedía se declarase a Buch en la clase de mercader alzado, fraudulento, doloso, substractor y robador público, indigno de la más leve indulgencia, repudiado de la equidad canónica, de la conmiseración de nuestra santa madre Iglesia y acrehedor a las más severas penas, por su comportamiento en su defensa y el tropel de diligencias que tan lastimosamente ha evacuado. Agravaba su responsabilidad el ser un comerciante instruido y estar en una plaza como Cádiz, en cituación tan crítica como la presente, en que son tan frequentes las quiebras como los días, dando lugar a substracciones con su mal exemplo. Tal era el caso que ya lo importante no era tanto recobrar las deudas como castigar al alzado. El fallo de la audiencia de la Contratación gaditana fue favorable a Batlle..$^{95}$

\footnotetext{
${ }^{94}$ AHFVizcaya, Sección Judicial, Corregimiento, 462/21, 40 folios. Se conserva, así mismo, la tercera pieza de este proceso, que incluye la oposición de Juana Joyce, mujer de Walcott, por sus dotales, valorados en 1.000 escudos de plata y 15 reales de vellón. En la tasación de las ropas y muebles de casa por vender se hallaron varios libros impresos (Fueros de Guipúzcoa, Ordenanzas nuevas del Consulado, gramáticas y diccionarios, libros de Historia, libros piadosos y de literatura, entre ellos, Don Quijote de la Mancha) (AHFVizcaya, Sección Judicial, Corregimiento, 390/15, 105 folios).

${ }^{95} \mathrm{AHN}$, Consejos [Consulado de Cádiz], 20.273, nº 6, 1ª pieza, fol. 184-275.
} 


\section{Conclusiones}

A la vista del material documental analizado resulta evidente que durante la Edad Moderna en los territorios castellanos se produjo un intenso esfuerzo de creación judicial de soluciones a las numerosas situaciones de insolvencia que se plantearon; Castilla, que en los tiempos medievales, había tenido una configuración agro-pecuaria predominante, con un desarrollo limitado de la vida comercial y crediticia, no disponía de soluciones eficaces para aquellos casos en que varios acreedores acudiesen a reclamar sus deudas a un mismo deudor, cuando las repúblicas italianas ya habían fijado sus procedimientos para ello.

Tras los primeros titubeos en los reinados de Enrique IV y Reyes Católicos, con la introducción de la graduación de créditos y la responsabilidad personal del deudor insolvente, mediante el uso de la argolla al cuello, se abre la vía de los llamados pleitos de acreedores, en los que ocupa un papel central la cesión de bienes, en especial, para los procesos voluntarios; alzamiento de bienes y actiones de dote protagonizarán el paralelo desarrollo de los pleitos forzosos; unos y otros pleitos confluirán en el paradigma del concurso de acredores, recogido en la literatura jurídica del siglo XVII, modelo que continuará así hasta fines del Antiguo Régimen, al menos.

Entretanto, la quiebra sufrirá un proceso mucho más tortuoso, como correspondía a un expediente de mucha mayor complejidad; durante el siglo XVI se ensayaron varios procedimientos, algunos de ellos muy visionarios, que sólo acabarían cristalizando en la quiebra bilbaína de las Ordenanzas consulares de 1737; pero hasta llegar allí se harían numerosos intentos de encontrar un camino, en cuyo estudio no se podrán poner todos los jalones precisos hasta no fijar con detalle cronologías, tribunales y procedimientos, en especial, en los ámbitos sevillano e indiano.

Por demás, el tradicional concurso de acreedores parece que fue la mejor opción para el Consulado de Bilbao hasta el primer tercio del siglo XVIII.

Junto a ambos paradigmas: concurso de acreedores y quiebra posterior a 1737, hemos pasado revista a otras figuras, unas adaptadas al modelo general (concursos de la nobleza o de los municipios), otras privilegiadas (expedientes de allanamiento, etc.). Mucho queda por hacer en la reconstrucción de estos vericuetos judiciales, aquí tan sólo se ha pretendido mostrar lo que la documentación permite atisbar. 